Deep Sea Research Part II: Topical Studies in Oceanography

August 2017, Volume 142, Pages 75-90

http://dx.doi.org/10.1016/i.dsr2.2017.01.008

http://archimer.ifremer.fr/doc/00369/48018/

(c) 2017 Elsevier Ltd. All rights reserved.

\title{
Origin and distribution of the organic matter in the distal lobe of the Congo deep-sea fan - A Rock-Eval survey
}

\author{
Baudin François ${ }^{1,}{ }^{*}$, Stetten Elsa ${ }^{1,2}$, Schnyder Johann ${ }^{1}$, Charlier Karine ${ }^{3}$, Martinez Philippe ${ }^{3}$, \\ Dennielou Bernard ${ }^{4}$, Droz Laurence ${ }^{5}$
}

\begin{abstract}
${ }^{1}$ Sorbonne Universités, UPMC-Univ. Paris 06, CNRS, Institut des Sciences de la Terre (ISTeP), UMR 7193, 4 place Jussieu, 75005 Paris, France

2 Sorbonne-Universités, UPMC-Univ. Paris 06, CNRS, Laboratoire d'Ecogéochimie des Environnements benthiques (LECOB), UMR 8222, Observatoire Océanologique, Banyuls-sur-Mer, France

${ }^{3}$ Université de Bordeaux, CNRS, Environnements et Paléoenvironnements Océaniques et Continentaux (EPOC), UMR 5805, Allée Geoffroy St Hilaire, 33615 Pessac Cedex, France

${ }^{4}$ IFREMER-Département REM, Unité des Géosciences Marines, 29280 Plouzané, France

${ }^{5}$ Université de Bretagne Occidentale - Institut Universitaire Européen de la Mer, CNRS, Laboratoire Domaines Océaniques (LDO), UMR 6538, 29280 Plouzané, France
\end{abstract}

* Corresponding author : François Baudin, email address : francois.baudin@upmc.fr

\begin{abstract}
:
The Congo River, the second largest river in the world, is a major source of organic matter for the deep Atlantic Ocean because of the connection of its estuary to the deep offshore area by a submarine canyon which feeds a vast deep-sea fan. The lobe zone of this deep-sea fan is the final receptacle of the sedimentary inputs presently channelled by the canyon and covers an area of $\sim 2500 \mathrm{~km}^{2}$. The quantity and the source of organic matter preserved in recent turbiditic sediments from the distal lobe of the Congo deep-sea fan were assessed using Rock-Eval pyrolysis analyses. Six sites, located at approximately $5000 \mathrm{~m}$ water-depth, were investigated. The mud-rich sediments of the distal lobe contain high amounts of organic matter ( 3.5 to $4 \%$ Corg), the origin of which is a mixture of terrestrial higher-plant debris, soil organic matter and deeply oxidized phytoplanktonic material. Although the respective contribution of terrestrial and marine sources of organic matter cannot be precisely quantified using Rock-Eval analyses, the terrestrial fraction is dominant according to similar hydrogen and oxygen indices of both suspended and bedload sediments from the Congo River and that deposited in the lobe complex. The Rock-Eval signature supports the $70 \%$ to $80 \%$ of the terrestrial fraction previously estimated using $\mathrm{C} / \mathrm{N}$ and $\delta 13 \mathrm{Corg}$ data. In the background sediment, the organic matter distribution is homogeneous at different scales, from a single turbiditic event to the entire lobe, and changes in accumulation rates only have a limited effect on the quantity and quality of the preserved organic matter. Peculiar areas with chemosynthetic bivalves and/or bacterial mats, explored using ROV Victor 6000 , show a Rock-Eval signature more or less similar to background sediment. This high organic carbon content associated to high sedimentation rates (> 2 to $20 \mathrm{~mm} . \mathrm{yr}-1)$ in the Congo distal lobe complex implies a high burial rate for organic carbon. Consequently, the Congo deep-sea fan represents an enormous sink of terrestrial organic matter when compared to other turbiditic systems over the world.
\end{abstract}


Keywords : recent sediments, Congo turbidite system, organic matter, Rock-Eval pyrolysis

\section{Introduction}

A classic but still relevant question in marine biogeochemistry and marine geology is the understanding of the fate of organic carbon (OC) delivered from the continent to the ocean (Benner, 2004; Blair \& Aller, 2012; Hedges and Keil, 1995; Hedges et al., 1997). Most terrestrial particulate organic carbon (POC) is delivered to the ocean by rivers with an annual total flux estimated between 200 and $500 \mathrm{Tg}$ C.yr-1 (Bianchi et al., 2014; Dagg et al., 2004; Degens et al., 1991; Ludwig et al., 1996; Meybeck, 1993, Schlünz and Schneider, 2000). Between $55 \%$ and $80 \%$ of the exported terrestrial OC is quickly remineralized along the continental margins (Burdige, 2005). The remainder is buried into sediments and mixed with autochthonous marine OC. Much of this preserved terrestrial fraction 
(40\% to $50 \%$ ) is stored in deltaic environments and the rest is dispersed along continental shelves, margins and deep oceanic settings (Berner, 1982, 2004; Burdige, 2005; Hedges and Keil, 1995). Today, because of a high sea-level stand, the major world rivers deposit their sediments -including the OC fraction- mainly on the continental shelves. By contrast, during sea-level falls related to glacial periods, most of the world rivers delivered their sediments into the deep ocean by the means of turbidite systems. Thus, globally, at the scale of glacial-interglacial cycles, the depocenter of the terrestrial OC flux into the oceans moved from proximal shallow marine (deltaic) to more distal deep marine (deep-sea fan) environments and vice versa. Only rivers directly connected to the deep ocean by a canyon can maintain an active turbidite system during high sea-level stands.

This is the case of the Congo River which drains the second largest watershed of the world $\left(3.710^{6}\right.$ $\mathrm{km}^{2}$ ) and concentrates about 38\% of the yearly run-off from Africa (Laraque et al., 2009; N'kounkou and Probst, 1987). Therefore, the Congo River system is a channelized continuum, from the watershed to the deepest distal zones of the deep-sea fan, via a single erosional canyon that penetrates into the estuary. Indeed, the Congo deep-sea fan receives continuous sedimentary inputs via turbidity currents (Heezen et al., 1964; Khripounoff et al., 2003; Vangriesheim et al., 2009) and remained permanently active during the Quaternary, regardless of sea level fluctuations (Droz et al., 1996, 2003; Marsset et al., 2009; Picot et al., 2016; van Weering \& van Iperen, 1984). The modern active turbidite system is restricted to a channel-levee-lobe that extends $760 \mathrm{~km}$ westward off the Congo-Angola margin (Savoye et al., 2000, 2009; Fig. 1A), but more than 80 inactive paleo-channels have been identified (Marsset et al., 2009).

For 30 years, substantial efforts have been made to study the terrestrial OC flux at the Congo River mouth (Cadée, 1984; Coynel et al., 2005; Kinga-Mouzéo, 1986; Mariotti et al., 1991; Spencer et al., 2012, 2014). The Congo River delivers yearly $\sim 5.510^{7} \mathrm{t}$ of sediment (Wetzel, 1993) and presents a high POC/suspended material ratio of $1 / 25$. Therefore the Congo ranks fifth in term of annual POC

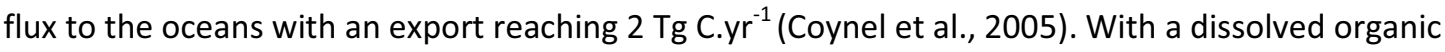
carbon (DOC) estimated to $12.4 \mathrm{Tg}$ C.yr ${ }^{-1}$, the Congo River is the second major exporter of terrestrial 
OC to the ocean after the Amazon River. At the Kinshasa-Brazzaville station, the \%POC is typically 6$7.5 \%$ of the suspended sediment (Spencer et al., 2012) and the \%DOC of total OC ranges from $80-$ 90\% (Coynel et al., 2005; Kinga-Mouzéo, 1986; Spencer et al., 2012). When suspended sediment is separated into coarse $(>63 \mu \mathrm{m})$ and fine $(0.7-63 \mu \mathrm{m})$ fractions, the POC ranges 5.7 to $11.8 \%$ in coarse fraction to $7.0-8.8 \%$ in the fine one (Spencer et al., 2012). Congo POC predominantly originates from C3 vascular plant vegetation and soil inputs as evidenced by elemental, isotopic and lignin phenol data (Mariotti et al., 1991; Spencer et al., 2012). The POC from the fine fraction shows an older ${ }^{14} \mathrm{C}$ signature ( $\sim 550 \mathrm{yr} \mathrm{BP}$ ) than POC from the coarse fraction, suggesting a more abundant contribution of soil OC in the fine fraction (Spencer et al., 2012). These authors observed little modification of organic matter concentrations and geochemical signatures between the Kinshasa-Brazzaville station and the mouth of the Congo River ( $350 \mathrm{~km}$ downstream), suggesting that the Kinshasa-Brazzaville station is a suitable reference point for constraining the Congo export of terrestrial $\mathrm{OC}$ to the Atlantic Ocean.

By contrast, little is known on the fate of $\mathrm{OC}$ after its entrance into the Atlantic Ocean. The incision of the canyon head enables normal marine waters to penetrate deep into the estuary (Cadée, 1984; Eisma and Kalf, 1984). A thin layer ( $\sim 10 \mathrm{~m})$ of fresh-water overflows this saline incursion. This surface layer, rich in fine sediment, $\mathrm{POC}$ and DOC, travels westwards and extend as a plume, up to $800 \mathrm{~km}$ from the coast. Except for some local areas of new production, supported by nutrient inputs from river-driven upwellings, $\mathrm{OC}$ concentration decreases gradually until the plume is no longer discernible (Cadée, 1984). All over the expansion of the plume, POC settles towards the seafloor, but this contribution is thought to be limited and does not represent an important sink of OC (see discussion in section 5.1). The Congo River also penetrates into the estuary as underflows, rich in sediment and POC, below the clear normal marine intermediate layer (Cadée, 1984; Pak et al., 1984). At the head of the estuary, this suspending material is concentrated and the POC is intensely remineralized (Eisma and Kalf, 1984). Downstream this area, the sediment flows to the depth with the turbidity currents following the path of the canyon to the abyssal plain. Our knowledge of the dispersion of 
the POC in the turbidite system is very limited if we consider that the entire Congo deep-sea fan covers a surface of $300,000 \mathrm{~km}^{2}$ (Savoye et al., 2009). Nevertheless, Rabouille et al. (2009) studied 4 sites along the course of the channel from its head (330 m water-depth) to its end (4800 m waterdepth). All these sites were located in areas potentially affected by the turbidity currents and were positioned on the border of the active channel, except for the deepest site which was positioned into the channel at the entrance of the distal lobe complex. At these different sites, POC deposition rates range from 0.9 to $2.2 \mathrm{molC} \cdot \mathrm{m}^{-2} . \mathrm{yr}^{-1}$, which is five to nine times greater than the settling of POC through the water column (Rabouille et al., 2009). In addition to downslope transport, the channellevee systems enable lateral export and deposition of sediment. Levees are developed all along the present-day active channel between $3800 \mathrm{~m}$ and $4800 \mathrm{~m}$ of water-depth, and are made up by overflows of the turbidity currents on both sides of the channel with a relatively symmetrical morphology (Babonneau, 2002; Babonneau et al., 2002, 2010; Savoye et al., 2009). The organic content of the levees is $3 \%$ in average and mostly derived from the Congo POC as evidenced by elemental, isotopic and organic molecular data (Baudin et al., 2010). A fourfold increase (from 0.8 to $\left.3.4 \mathrm{~mm} . \mathrm{yr}^{-1}\right)$ in accumulation rates between upfan and downfan has a little impact on the quality of buried organic matter (Baudin et al., 2010). At the lobe site, elemental and organic biomarkers data, such as linear alcohols measured by Treignier et al. (2006), point also to a large fraction of terrestrial OC in the sediment. Detrital POC flux exceeds hemipelagic POC rain by one order of magnitude, and two-thirds of the POC deposited ends up buried in the lobe sediments (Rabouille et al., 2009). An extrapolation of this result to the surface of the entire lobe yields an enormous OC burial depocenter that may account for an accumulation of $0.4 \mathrm{Tg} \mathrm{C.yr}^{-1}$ (Rabouille et al., 2009). This suggests that about one-fifth of the POC delivered by the Congo River is ultimately buried in the lobe complex making the Congo deep-sea fan a very efficient sink of POC into the deep ocean if we consider the total OC burial in the South Atlantic (1.8 Tg C.yr ${ }^{-1}$; Mollenhauer et al., 2004) and the global annual deep-sea burial (10-20 Tg C.yr ${ }^{-1}$; Berner, 1982; Hedges and Keil, 1995). 
The Congolobe project aims, among others, to verify this hypothesis by studying the whole lobe complex. This paper presents a bulk geochemical survey of the main parts of the distal lobe complex using material recovered during two oceanographic campaigns onboard the R/V Pourquoi Pas?, the WACS (Olu, 2011) and Congolobe (Rabouille, 2011) cruises. A previous study (Stetten et al., 2015) presented and discussed $\mathrm{C} / \mathrm{N}$ and $\delta^{13} \mathrm{C}_{\text {org }}$ data on 9 multitubes. This study enlarges the data set (28 cores in total), discusses the controlling factors of the organic sedimentation in this area and provides new insights that can be used to evaluate the fate of terrestrial organic matter in the oceans at short and millennial term scales.

\section{Sedimentological setting}

The WACS and Congolobe campaigns investigated 6 sites, between $4750 \mathrm{~m}$ and $5050 \mathrm{~m}$ water-depth, in the relatively flat lobe zone at the end of the present-day active turbidite system, where most turbidity currents die and lose the material held in suspension by turbulence (Fig. 1B). Savoye et al. (2000, 2009), Babonneau (2002), Bonnel (2005) and Dennielou et al. (this volume) showed that the unique active channel runs into a lobe complex made of a series of 5 lobes mainly developed on the right-hand side of the channel (Fig. 1B). This lobe complex has a bunch of grapes-like prograding downstream organization along about $100 \mathrm{~km}$. Therefore, individual lobes are characterized by a downstream age decrease, from ca 4 ka to present (Picot, 2015) and were numbered from 1 to 5 from upstream to downstream (Fig. 1B).

The 6 sites studied during WACS and Congolobe campaigns were chosen with the purpose of investigating areas of various ages and of different settings on the lobe complex (Fig. 1B). Sediments were recovered using either a multicorer MUC 8/100 Oktopus, the ROV Victor 6000 core-tube sampler or a Calypso piston corer (Kullenberg-type). The cores recovered with these different tools were labelled MTB, CT and CS, respectively. The description of the studied sites (Fig. 1B) is summarized below and further information is given in Rabouille et al. (this volume) and Dennielou et al. (this volume): 
- Site A is located at the entrance of the lobe complex, which is also the entrance of the oldest, most upstream lobe (\#1) of the complex. A 900 m-wide meander of the active-channel was investigated at water-depth between 4745 and $4790 \mathrm{~m}$. The Calypso piston core (CoL-ACS01) studied here was recovered on the flat levee north to the active-channel. A ROV dive during the WACS campaign allowed collecting a pushcore (WACS-A-PL435-CT08, Fig. 2a) on the northern levee of the channel in an area where large concentrations of vesicomyid bivalves were observed. Two multitubes (WACS-A-MTB03 and CoL-A-MTB02) were recovered in the same area. Another multitube (CoL-A-MTB03) was sampled on the southern internal flank of the channel, where vesicomyids are also abundant.

- $\quad$ Site B, located 22 km north-westwards from site A, explored the distal part of the lobe \#3 (Fig. 1B). A Calypso piston core (CoL-B-CS07) and a multitube (CoL-B-MTB12) were sampled on the left-hand (southern) levee of the former channel by $4820 \mathrm{~m}$ of water-depth.

- Site F is located in the active-channel $40 \mathrm{~km}$ downstream of site A, just at the entrance of the youngest lobe (\#5) (Fig. 1B). The channel is wider ( $2.5 \mathrm{~km})$ at this site compared to site A. A Calypso core (CoL-F-CSO3) was sampled at $4886 \mathrm{~m}$ water-depth in the levee sediments on the right-hand (western) flank of the channel. Multitube sampling (CoL-F-MTB05) was associated with this Calypso core in order to investigate organic matter recycling on the levees.

- $\quad$ Site C is located $25 \mathrm{~km}$ from site F at $\sim 4940 \mathrm{~m}$ water-depth in the distal part of the youngest lobe (\#5). Two Calypso cores were studied in this area: CoL-C-CS04, at $4949 \mathrm{~m}$ water-depth, located on the northern border of the channel, and CoL-C-CSO6, at $4954 \mathrm{~m}$ water-depth, in the channel. A multitube (CoL-C-MTB06) was collected on the northern limit of the filled channel and two others (CoL-C-MTB-11 and WACS-C-MTB04) were collected within the sediments near dense chemosynthetic habitats of bivalves. Several ROV dives were achieved in the central and northern part of the filled channel. The first dive (PL 436) allowed collecting cores in potential microbial mats (WACS-C-PL436-CT11, Fig. 2b). All other dives (PL 437-490-491) were devoted to sample different types of dense chemosynthetic habitats. 
Two areas with large concentrations of vesicomyid bivalves were particularly studied, one having the shape of a mouth and the other having the shape of a heart. The mouth-shape vesicomyid habitat was studied here using 2 ROV pushcores (WACS-C-PL437-CT02 and 08, Fig. 2c) whereas the heart-shape vesicomyd habitat was sampled by 3 cores (CoL-C-PL491CT01, 05 and 14, Fig. 2d). Reduced sediments were analyzed in two places, one showing a large black patch (CoL-C-PL490-CT13 and 15, Fig. 2e) and the other in an area with white and black patches on top of the sediment (CoL-C-PL490-CT03 and 05), being possibly microbial mats.

- Site D was investigated during the WACS campaign in a flat area by $5030 \mathrm{~m}$ water-depth. This site is located $18 \mathrm{~km}$ south-westwards from site $\mathrm{C}$ outside the limit of the lobe complex as shown on Fig. 1B, but in a place not so far ahead from the youngest lobe $\# 5$ where turbidity currents have possibly some influences and have deposited a faint bulge of sediments. A dive in this zone was achieved at the outer edge of the deposition area and allowed collecting two pushcores (WACS-D-PL438-CT02 and 05, Fig. 2f) that are studied here. A 19.8 m-long Calypso piston core, located between sites D and C and called WACS-06, was retrieved at $4996 \mathrm{~m}$ water depth few kilometres in front the end of the terminal lobe. More details about this site and Calypso core are presented by Croguennec et al. (this volume).

- Site $E$, located approximately $45 \mathrm{~km}$ to the north of site A, explored the feeding channel of the previous lobe complex, which is disconnected from the active channel since at least the Holocene and is interpreted as abandoned for several thousand years (Babonneau 2002, Bonnel 2005; Picot 2015). One multitube (CoL-E-MTB14), sampled at this site, provides a reference for the onset to the background hemipelagic sedimentation after the turbiditic deposition breaks off.

\section{Material and methods}

\subsection{Samples}


A total of 473 samples were analyzed from 28 cores collected during both the WACS and Congolobe campaigns (Tab. 1). In this study, 9 MTB, 13 CT and 6 CS cores were selected at the different sites described above. After retrieval, the cores were stored at $4{ }^{\circ} \mathrm{C}$ prior to their description and sampling. For short cores (MTB and CT) slicing was usually as follows: $0-0.5 \mathrm{~cm} ; 0.5-1 \mathrm{~cm} ; 1-2 \mathrm{~cm} ; 2-3 \mathrm{~cm} ; 3-5$ $\mathrm{cm} ; 5-7 \mathrm{~cm} ; 7-10 \mathrm{~cm} ; 10-13 \mathrm{~cm} ; 13-16 \mathrm{~cm} ; 16-19 \mathrm{~cm} ; 19-22 \mathrm{~cm}$. Aliquots of each sliced sample were homogenized and then stored wet at $4{ }^{\circ} \mathrm{C}$ before sedimentological analyses. Aliquots for geochemical purposes were freeze-dried (CoL samples) or oven-dried (WACS samples) and then crushed in an agate mortar to obtain a fine and homogeneous powder. The samples were stored at room temperature till their analysis.

To complete this dataset, 20 samples of sediment trap (ST) were recovered $45 \mathrm{~m}$ above seafloor at Site A (4750 m-depth; S $\left.6^{\circ} 27.95^{\prime}, \mathrm{E} 6^{\circ} 01.83^{\prime}\right)$ during the 10 month interval between WACS and Congolobe campaigns and with a sampling duration of two weeks. Details on this mooring are described in Rabouille et al. (this volume). Lastly, 6 samples from the Congo River bed-load, bank and floodplain collected near Kinshasa were also analyzed. These two sets of samples provide references for marine and terrestrial end-members, respectively.

\subsection{Analytical methods}

Sedimentary facies were determined by visual description for all studied CS cores. Such detailed examination was not possible on MTB and CT cores as they were rapidly sliced, sampled and frozen on-board. Nevertheless, pictures of sediment through the transparent tube have been taken before slicing and a visual description of every slice was done (i.e. Figs. 5 and 8). Grain size analyses for MTB cores and some CT cores were performed using a laser granulometer Mastersizer 2000 (Malvern Instruments). Grain size analysis data on MTB cores were presented and described in Stetten et al. (2015).

Carbonate content was measured either using a carbonate bomb, with an analytical precision of $\pm 0.5 \% \mathrm{CaCO}_{3}$, or using the Rock-Eval apparatus (see below). 
Pyrolytic analyses were carried out using a Rock-Eval 6 Turbo device (Vinci Technologies), operating in a mode which is devoted to recent marine sediments (Baudin et al., 2015). This mode necessitates washing the samples before analysis to avoid disturbance related to $\mathrm{NaCl}$ and starting the pyrolysis at $180^{\circ} \mathrm{C}$ to avoid decomposition of the most labile components of the organic matter. Briefly, the Rock-Eval technique provides several fundamental parameters (Behar et al., 2001; Espitalié et al., 1985; Lafargue et al., 1998): the first peak (S1) corresponds mainly to free hydrocarbons that are volatilized for 3 minutes at $180^{\circ} \mathrm{C}$ and detected by a Flame Ionization Detector (FID). The second peak (S2) represents hydrocarbons generated from kerogen cracking between 180 ${ }^{\circ} \mathrm{C}$ and $650^{\circ} \mathrm{C}$. The amounts of $\mathrm{CO}_{2}$ and $\mathrm{CO}$ released during pyrolysis are detected by an infra-red (IR) cell and represent the $\mathrm{S} 3$ and $\mathrm{S} 3 \mathrm{CO}$ peaks, respectively. All these parameters are expressed in $\mathrm{mg}$ of hydrocarbons or $\mathrm{CO}_{2} / \mathrm{CO}$ per gram of rock. Temperature at which the maximum of hydrocarbons are yielded by the kerogen is called $\operatorname{Tmax}\left(\right.$ in ${ }^{\circ} \mathrm{C}$ ). The residual organic and inorganic carbon content (in wt \%) is obtained by combustion in air from $300{ }^{\circ} \mathrm{C}$ to $850{ }^{\circ} \mathrm{C}$. The $\mathrm{CO}_{2}$ and $\mathrm{CO}$ issuing from this combustion are also detected by an IR cell and correspond to peaks $\mathrm{S} 4$ and $\mathrm{S} 5$ for $\mathrm{CO}_{2}$ and peak $\mathrm{S} 4 \mathrm{CO}$ for CO. From these basic parameters, the total organic carbon content (TOC, in wt \%) is calculated as the sum of pyrolyzed and residual organic carbon. The hydrogen index $(\mathrm{HI})$ corresponds to the quantity of pyrolyzable organic compounds from S2 relative total organic carbon (in $\mathrm{mg} \mathrm{HC} . \mathrm{g}^{-1} \mathrm{TOC}$ ) and the oxygen index (OI) to the $\mathrm{S} 3$ relative total organic carbon (in $\mathrm{mg} \mathrm{CO}_{2} \cdot \mathrm{g}^{-1} \mathrm{TOC}$ ). Finally, the mineral carbon $(\mathrm{MinC})$ is also calculated on the basis $\mathrm{S}^{\prime}$ and $\mathrm{S}^{\prime} \mathrm{CO}+\mathrm{S} 5$ peaks. This MinC can be converted to $\mathrm{CaCO}_{3}$ if we assume that all inorganic carbon is under the form of calcite or aragonite. The precision for the parameters is $\pm 0.1 \%$ for TOC, $\pm 0.05 \%$ for MinC, $\pm 2{ }^{\circ} \mathrm{C}$ for Tmax, $\pm 10 \mathrm{mg} \mathrm{HC} . \mathrm{g}^{-1}$ TOC for $\mathrm{HI}$ and $\pm 5 \mathrm{mg} \mathrm{CO} \cdot \mathrm{g}^{-1} \mathrm{TOC}$ for OI.

$\mathrm{C} / \mathrm{N}$ mass ratios, and stable isotope composition of carbon were determined by on-line combustion on samples from CT cores ( $\mathrm{n}=91$ samples) and ST samples (20 samples) in a Thermo Fischer Flash 2000 Elemental Analyzer connected to an Isoprime isotope ratio mass spectrometer. Prior to isotopic measurements, samples were acidified with $1 \mathrm{~N} \mathrm{HCl}$ to remove the inorganic carbon 
then rinsed with deionized water. The ${ }^{13} \mathrm{C} /{ }^{12} \mathrm{C}$ ratios are expressed using the conventional $\delta$ notation relative to the values measured in the PeeDee Belemnite (PDB) for carbon. The analytical precisions are $\pm 0.15 \%$ for $\delta^{13} \mathrm{C}_{\text {org. }} \mathrm{C} / \mathrm{N}$ mass ratios were obtained by measuring total organic carbon (TOC) and total nitrogen (TN) on acidified samples. Both $\mathrm{C} / \mathrm{N}$ ratios and isotopic data for 77 samples from the MTB cores and the CoL-C-CSO6 long core were presented and discussed elsewhere (Stetten et al., 2015).

\section{Results}

Calcium carbonate content of turbidite facies remains very low $(<7.5 \%)$ with an average around $3.9 \%$ (Table S1 in supplementary data). Thus, the sediment can be regarded as virtually devoid of particulate carbonate. This is not surprising as the lobe complex is situated at depths close to or below the calcium carbonate compensation bottom limit in that part of the Atlantic Ocean (Jansen et al. 1984) and because the suspended material delivered by the Congo River does not contain carbonate particles. Such low values were also reported in sediments from the channel-levee system of the Congo deep-sea fan around $4000 \mathrm{~m}$ water-depth (Baudin et al., 2010). Consequently, only the organic matter content of the studied sediments is presented and discussed below.

\subsection{Organic matter distribution in long Calypso piston-cores}

The visual description of piston-cores reveals that most sediment recovered at sites F, C, B and D is strongly deformed, with evidence of slumps in cores CoL-F-CSO3 and CoL-C-CSO4. Dislocation is also noted as large clasts and disturbed levels are observed throughout cores CoL-C-CSO6, CoL-B-CSO7 and WACS-06 and also observed at several spatial scales on videos and on the high-resolution morphology (Dennielou et al., this volume). These deformation and displacement features do not imply long transport as the initial bedding is always identifiable (see discussion in Croguennec et al., this volume). The ${ }^{210} \mathrm{~Pb}$ profiles of cores CoL-C-CSO6 and CoL-B-CSO7 showing a regular decrease with 
depth, suggest that the intense reworking is almost constant through the last 60 years (Rabouille et al., this volume). By contrast, core CoL-A-CSO1 exhibits a regular undisturbed succession of fine clayey turbidites ( 2 to $5 \mathrm{~cm}$-thick) alternating with silty-sandy turbidites ( 5 to $20 \mathrm{~cm}$-thick) along the $11.5 \mathrm{~m}$ of penetration. This suggests a longer record of deposits by turbidity currents and a lower sedimentation rate as evidenced by lower ${ }^{210} \mathrm{~Pb}_{\mathrm{xs}}$ activity in this core (Rabouille et al., this volume). TOC content in studied piston-cores fluctuates between 3 and $4 \%$ in the clayey facies with values reaching 5.2\% in some levels (Fig. 3). As already reported in the channel-levee system (Baudin et al., 2010), TOC contents are much lower in the sandy turbiditic facies (0.1 to $1.3 \%)$. Although only few cores were analyzed, a trend for increased organic richness may be depicted from the proximal site A to the distal site $\mathrm{C}$. This increase reaches $0.5 \%$ TOC on average and the highest values are consistently recorded in cores from site C. Core CoL-B-CSO7 shows high variations in TOC content that are related to the contrasted facies in this core (Fig. 3). Core WACS-06 exhibits the greatest range of variation of TOC contents, with values fluctuating between 0.55 and $1.2 \%$ in hemipelagic facies, whereas the turbiditic facies display higher TOC contents, up to $4.4 \%$ (for a detailed analysis of this core see Croguennec et al., this volume).

HI values fluctuate between 55 and $210 \mathrm{mg} \mathrm{HC} \cdot \mathrm{g}^{-1} \mathrm{TOC}$ with a mean-value around $145 \mathrm{mg} \mathrm{HC} \cdot \mathrm{g}^{-1} \mathrm{TOC}$ in all studied CS cores (Fig. 3). Such HI values are extremely constant if we consider that this parameter may theoretically fluctuate from 0 to 1000 (Espitalié et al., 1985). Ol values fluctuate between 115 and $585 \mathrm{mg} \mathrm{CO} 2 \cdot \mathrm{g}^{-1} \mathrm{TOC}$ with a mean-value around $250 \mathrm{mg} \mathrm{CO} 2 \cdot \mathrm{g}^{-1} \mathrm{TOC}$. The highest OI values are recorded both in coarse turbiditic sandy layers of cores CoL-B-CS07 and CoL-C-CSO6 and organic-lean hemipelagic clays of core WACS-06, suggesting a strong alteration of the organic matter preserved in such facies (Fig. 3).

\subsection{Organic matter distribution in short multitube-cores}

Despite they were collected in various environments (channel, levees, filling or erosive areas) with high but contrasting accumulation rates (see Rabouille et al., this volume), background sediments 
from sites A, F, C and B show relatively similar sedimentological and organic characteristics (Fig. 4). Grain-size determinations indicate that most of the sediment is made of clayey and silty fractions (up to $85-100 \%$ ) with a median grain-size around $10 \mu \mathrm{m}$ (Stetten et al., 2015). The sandy fraction usually represents less than $10 \%$ to $20 \%$ and is only present in discrete layers. TOC contents are very homogeneous with a mean value around $3.2 \%$. The topmost 2 to $3 \mathrm{~cm}$ of each MTB cores usually shows a slight upward decrease in TOC (0.5 wt\% in average).

Sediments from site $\mathrm{C}$ show wider TOC variations with values reaching $4.3 \%$ in core CoL-C-MTB11 and values as low as $2.15 \%$ in core WACS-C-MTB04. HI values fluctuate between 110 and $190 \mathrm{mg}$ $\mathrm{HC} . \mathrm{g}^{-1}$ TOC with a mean value around $150 \mathrm{mg} \mathrm{HC} \cdot \mathrm{g}^{-1} \mathrm{TOC}$ in all studied cores. Ol values fluctuate between 185 and $400 \mathrm{mg} \mathrm{CO} 2 \cdot \mathrm{g}^{-1} \mathrm{TOC}$ with a mean value around $275 \mathrm{mg} \mathrm{CO} \cdot \mathrm{g}^{-1} \mathrm{TOC}$ in cores from sites $\mathrm{A}, \mathrm{F}, \mathrm{C}$ and $\mathrm{B}$. The range of $\mathrm{Ol}$ variations is quite large and probably indicates different degrees of oxidation of the organic matter.

Sediments from site E show remarkable differences with those from the recent lobe complex. As already mentioned by Stetten et al. (2015), the first $7 \mathrm{~cm}$, made of hemipelagic brown ooze, are characterized by lower TOC percentages (1.5\%), whereas TOC content increases downward and finally resembles those of the lobe complex at a depth of $20 \mathrm{~cm}$. HI and Ol also show a contrasted behaviour between the first $7 \mathrm{~cm}$ with lower $\mathrm{HI}\left(\sim 90 \mathrm{mg} \mathrm{HC} \cdot \mathrm{g}^{-1} \mathrm{TOC}\right.$ ) and higher Ol-values (up to 540 mg CO $2 . g^{-1}$ TOC; Fig. 4).

\subsection{Organic matter distribution in push-cores collected in chemosynthetic habitats}

Reduced sediments, characterized by black patches at the water/sediment interface (Fig. 2e), were cored at difference places of the ending channel of site $\mathrm{C}$. The recovered sediment is uniformly black whatever the core and its penetration (from 4 to $20 \mathrm{~cm}$-depth; Fig. 5). TOC contents in this reduced sediment are usually higher than in the background sediment recovered using the multicorer (MTB cores), with values up to $5.4 \%$ (Fig. 5). Highest values are observed at the top of the core and a downward decrease in TOC is obvious, although the TOC content remains high ( $\sim 4.5 \%)$ at the bottom 
of the cores (Fig. 5). HI values decrease from 175 to $125 \mathrm{mg} \mathrm{HC} . \mathrm{g}^{-1}$ TOC along the studied cores, whereas OI values are more or less constant around $250 \mathrm{mg} \mathrm{CO} \cdot \mathrm{g}^{-1} \mathrm{TOC}$. Since inputs of organic materials from the zone must be similar, the black patches observed at site $\mathrm{C}$ likely correspond to area of methane escape from the sediment, the black colour indicating oxygen depletion due to the oxidation of methane. As shown by Hinrichs et al. (2000) organic matter preservation in such setting is particularly favoured, because the input of methane stimulates a bacterial community that is able to capture sulfate that would otherwise be used in the remineralization of organic matter. The higher TOC values observed in the sediments of the black patches at site $C$ are consistent with such methane oxidation processes that are widespread in the lobe complex (Pastor et al., this volume). The microbial mat collected at site C (Fig. 2b) shows an increase of TOC contents with depth, from $2.8 \%$ at the top to $3.4 \%$ below $13 \mathrm{~cm}$-depth (Fig. 6). The topmost layers ( 0.5 to $2 \mathrm{~cm}$ ) show higher HIvalues and lower Ol-values than the in-depth samples. A slight increasing trend in $\delta^{13} C_{\text {org }}$ values is noted through depth in this microbial mat with values of around $-28 \%$ at the top up to $-27 \%$ at the base, as well as an increase of $\mathrm{C} / \mathrm{N}$ values from 12 to 15 .

CT collected at the fringe of vesicomyid habitats at site C (Fig. 2c) are characterized by a steady TOC content ( 3\%) through depth (Fig. 7). HI values do not vary and are centred on $175 \mathrm{mg} \mathrm{HC} . \mathrm{g}^{-1} \mathrm{TOC}$, whereas $\mathrm{Ol}$ values show greater variation with a range between 150 and $325 \mathrm{mg} \mathrm{CO}_{2} \cdot \mathrm{g}^{-1} \mathrm{TOC}$. Such values are very similar to those of the background sediment studied in MTB cores (see section 4.2 and Fig. 4). In one of the two studied cores, the TOC, $\mathrm{HI}$ and $\mathrm{OI}$ parameters show a sharp excursion between 5 and $7 \mathrm{~cm}$-depth, an interval corresponding to the penetration-depth of vesicomyids in these chemosynthetic habitats (Karine Olu, pers. comm.). High $\delta^{13} \mathrm{C}_{\text {org }}$ values of around $-27 \%$, and high $\mathrm{C} / \mathrm{N}$ values ( $\sim 15)$ were measured on these $\mathrm{CT}$ cores of site $\mathrm{C}$ (Fig. 7).

A CT core collected into a vesicomyid habitat at site A (Fig. 2a) shows a regular decrease in TOC through depth, from $2.7 \%$ at the top to $1.8 \%$ at the base (Fig. 7). HI values decrease and Ol values increase with depth, which suggests a stronger alteration of the organic content with respect to the 
TOC attenuation. No peculiar evolution is noted for $\delta^{13} \mathrm{C}_{\text {org }}$ values ( $\sim-26.8 \%$ ) and $\mathrm{C} / \mathrm{N}$ values $(\sim 15)$ in this sediment (Fig. 7).

Interestingly, the results around the heart-shape vesicomyid habitat (Fig. 2d) yield slightly different results. The core CoL-C-PL491-CT14 collected in sediment adjacent to the vesicomyids shows high TOC content (4.2\% in average) with a slight decrease at the base (Fig. 8). HI values are almost constant (150 mg HC. $\mathrm{g}^{-1} \mathrm{TOC}$ ) and OI values are decreasing through depth, suggesting that the organic matter is better preserved downward. Core CoL-C-PL491-CT05 collected in the fringe of vesicomyid habitat displays lower TOC content compared to adjacent sediment, with a slight regular decrease with depth (Fig. 8). HI and OI values are more scattered than in any other sediment. Core CoL-C-PL491-CT01 collected at the fringe of the vesicomyid-heart exhibits the lowest TOC values with a more pronounced decrease of TOC through depth (Fig. 8). A general increasing trend in $\delta^{13} \mathrm{Corg}_{\text {or }}$ values is noted through depth in the vesicomyid habitats (CT1 and CT5) with values of around -27\%o at the top up to $-25.4 \%$ at the base $(13 \mathrm{~cm})$, whereas the $\delta^{13} \mathrm{C}_{\text {org }}$ values in the adjacent sediment (CT14) is almost constant around $-26.3 \%$. A downward increase in $\mathrm{C} / \mathrm{N}$ values (from 12 to 15 or even 16) characterizes these CT cores, whatever the environment (Fig. 8). It should be noted that this $\mathrm{C} / \mathrm{N}$ increase is less pronounced in the adjacent sediment compared to the vesicomyid habitat. The higher TOC content in the background sediment compared to the sediment in fringing zone of the vesicomyid habitat suggests an active recycling of organic matter by the benthic macro- and microfauna.

Cores WACS-D-PL438-CT02 and 05, collected outside the limit of the lobe complex in a zone inhabited by the benthic agglutinate foraminifera Bathysiphon (Fig. 2f), show a general decrease in TOC through depth, from 3.2 to $2.8 \%$ (Fig. 9, Table S1). This general trend is interrupted by levels with very high TOC contents between 1 and $4 \mathrm{~cm}$-depth. HI values range from 150 to $225 \mathrm{mg} \mathrm{HC} . \mathrm{g}^{-1}$ TOC and OI values from 120 to $280 \mathrm{mg} \mathrm{CO} \cdot \mathrm{g}^{-1} \mathrm{TOC}$ (Table S1). No peculiar evolution is noted for $\delta^{13} C_{\text {org }}$ values ( $-26.3 \%$ ) whereas $\mathrm{C} / \mathrm{N}$ values are scattered between 15.2 and 19.7 in this sediment (Fig. 9). 


\subsection{Organic matter in sediment trap at site $A$}

At the entrance of the lobe complex, the mean total flux of settling particles was $63.2 \mathrm{mg} \cdot \mathrm{m}^{-2} \cdot \mathrm{d}^{-1}$ with a maximum of $100 \mathrm{mg} \cdot \mathrm{m}^{-2} \cdot \mathrm{d}^{-1}$ in March 2011 and a minimum of $33 \mathrm{mg} \cdot \mathrm{m}^{-2} \cdot \mathrm{d}^{-1}$ in September 2011 (Alexis Khripounoff, pers. comm.). The organic carbon content in trapped sediment, measured using Rock-Eval apparatus, ranges from 3.9 to 5.6 wt\% with an average of $4.8 \%$ TOC, whereas the inorganic carbon content ranges from 3.1 to $6.4 \%$ with an average of $4.8 \%$ ( $40 \% \mathrm{CaCO}_{3}$ equivalent; Table 2$)$. $\mathrm{HI}$-values vary from 255 to $340 \mathrm{mg} \mathrm{HC} . \mathrm{g}^{-1} \mathrm{TOC}$ and OI values from 172 to $254 \mathrm{mg} \mathrm{CO} 2 \cdot \mathrm{g}^{-1} \mathrm{TOC}$. C/N ratios are extremely constant ( 8.3 in average) and $\delta^{13} C_{\text {org }}$ values range from -24.4 to $-22.7 \%$ with an average of $-23.7 \%$ (Tab. 2).

\subsection{Rock-Eval signature of Congo River sediments collected on land}

Surface and subsurface samples from bedload, river bank and floodplain collected near Kinshasa contain lower organic carbon than the suspended sediment studied by Spencer et al. (2012). TOC content of the bedload and floodplain sediment is 1.35 and $1.45 \%$ respectively, while the river-bank sediment is richer (2.5\%, Table 2). These values, measured using Rock-Eval apparatus, are similar to those reported by Talbot et al. (2014) on the same material. HI-values are almost constant (165 to $180 \mathrm{mg} \mathrm{HC}^{-1} \mathrm{~g}^{-1} \mathrm{TOC}$ ) whatever the type of riverine sediment (Table 2). The Ol-values of river-bank are higher (>300 $\mathrm{mg} \mathrm{CO}_{2} \cdot \mathrm{g}^{-1} \mathrm{TOC}$ ) than the bedload and floodplain sediment which display OI-values < $265 \mathrm{mg} \mathrm{CO} \cdot \mathrm{g}^{-1} \mathrm{TOC}$.

\section{Discussion}

On the basis of our Rock-Eval data, the following sections will discuss the source of organic matter preserved in the lobe zone of the Congo deep-sea fan, consider the controlling factors for organic matter sedimentation in this zone, and finally examine the implication of this study for other deepsea fans. 


\subsection{Sources of organic matter and estimation of the terrestrial organic carbon contribution}

The nature of organic matter can be determined using Rock-Eval pyrolysis by the mean of S2-TOC cross-plot (Dahl et al., 2004; Langford and Blanc-Valleron, 1990) or HI-Ol cross-plot (Espitalié et al., 1977,1985 ) if the thermal evolution of organic matter is moderate (Espitalié et al., 1985; Peters, 1986). Indeed, measured Tmax values in sediments from the terminal lobes of the present-day Congo deep-sea fan are always low $\left(<420^{\circ} \mathrm{C}\right)$, indicating that the bulk organic matter did not experience strong thermal maturation and therefore contains very little charcoals or recycled material from older mature rocks. Consequently, the two cross-plots mentioned above may be used for typing the source of organic matter in the studied sediments.

In the S2-TOC cross-plot (Fig. 10A), samples from the lobe sites with TOC $>2 \%$ are located between the two lines corresponding to $\mathrm{HI}$ values of 100 and $200 \mathrm{mg} \mathrm{HC} \cdot \mathrm{g}^{-1} \mathrm{TOC}$. Such values are typical of Type III kerogen, related to terrestrial higher-plants debris (Durand, 1980; Tissot and Welte, 1984). All these samples correspond to turbiditic sediments collected at sites A, B, C, D and F. Samples from the Congo River bedload and floodplain are located between the same lines in the S2-TOC cross-plot (Fig. 10A) suggesting that this fluvial source is the main contributor of the organic matter deposited in the terminal lobes of the Congo deep-sea fan. Samples with $\mathrm{TOC}<2 \%$ show lower $\mathrm{HI}$ values ranging from 50 to $100 \mathrm{mg} \mathrm{HC} . \mathrm{g}^{-1} \mathrm{TOC}$ and are representative of hemipelagic sediments from both site $E$ and those recovered in the long core from site $D$. Sediment collected in the trap at site $A$ are located around the line of $\mathrm{HI}=300 \mathrm{mg} \mathrm{HC} \cdot \mathrm{g}^{-1} \mathrm{TOC}$, suggesting higher amount of hydrogen-rich moieties in the organic matter settling from the surface.

In the HI-OI cross-plot (Fig. 10B), samples from long piston-cores show a wider dispersion than samples coming from MTB and CT ROV. This may be explained by the diversity of facies recovered along these cores and because some of these facies (sand, hemipelagic ooze, ...) are organic-lean with more degraded organic matter. Indeed, samples with high OI values (>350) are related to hemipelagic oozes from site D and the topmost layers of site E. Such facies contain a more oxidized 
organic matter and refer to Type IV kerogen which corresponds to residual, deeply altered organic matter. The comparison of $\mathrm{HI}$ and $\mathrm{OI}$ values of pure organic moieties or higher-plants and plankton components with samples from the terminal lobes of the Congo deep-sea fan indicates a strong alteration of the organic matter whatever the source (Fig. 10B). The Ol values of cellulose, pectin, lignin, bark and needle (values recalculated from Carrie et al., 2012) are much higher than those of organic matter delivered by the Congo River and deposited in the turbidite system. This implies a strong alteration of the organic matter in the watershed with a preferential loss of functionalized oxygen-rich moieties (alcohol, ester, ether, acid, ...). Similarly, the HI values of phytoplankton and copepods (Carrie et al., 2012) are three times higher than the value of sediment trapped $45 \mathrm{~m}$ above the lobe. Though the marine origin of the organic matter settling throughout the water column is obvious according to its $\mathrm{C} / \mathrm{N}$ ratio (around 8 ), its degradation seems important with a preferential loss of hydrogen-rich moieties. According to $\mathrm{C} / \mathrm{N}$ ratio and $\delta^{13} \mathrm{C}_{\text {org }}$ values of trapped sediment, the terrestrial fraction originating from the end of the surficial plume is very limited.

Our Rock-Eval pyrolysis data fully confirm the nature of organic matter determined by elemental and isotopic analysis on MTB cores (Stetten et al., 2015). Using a "two end-members" mixing model based on carbon isotopic values, Stetten et al. (2015) estimate that the relative proportion of the terrestrial fraction within the organic matter from the lobe sediments range from 70 to $80 \%$. Our Rock-Eval data are in agreement with such a proportion. As the $\mathrm{HI}$ and $\mathrm{OI}$ values of the sediment delivered by the Congo River are almost equal to those measured in lobe sediments and because the marine organic matter settling from surface display higher $\mathrm{HI}$ values, it could be inferred that the fluvial source is largely dominant. This assertion is also supported by visual observation of the organic matter, the so-called palynofacies, which reveals a very large proportion of well-preserved higherplant remains in the lobe sediments. Preliminary results on palynofacies were reported by Stetten et al. (2015) and a more complete analysis of palynofacies is presented elsewhere (Schnyder et al., this volume). Gelified orange to black organic particles observed in palynofacies, as well as branched and 
isoprenoid tetraether (BIT) index values between 0.75-0.84 measured on MTB cores by Stetten et al.

(submitted) support a dominant soil origin of the organic matter in the actual Congo lobe complex.

The sources of organic matter into the habitats explored during the ROV survey are roughly the same according to Rock-Eval data (Fig. 10). Nevertheless, some differences arise when considering the elemental and isotopic signatures of chemosynthetic habitats. Figure 11 shows the $\mathrm{C} / \mathrm{N} v s \delta^{13} \mathrm{C}_{\text {org }}$ cross-plot of sediment samples in vesicomyid and microbial habitats compared to the background sediment of MTB cores (data from Stetten et al., 2015). Most of the studied samples from particular habitats plot in the same area as the background sediment (Fig. 11). Only one vesicomyid habitat (the heart-shape structure) and the microbial mat show a different geochemical signature with a general trend for decreasing $\mathrm{C} / \mathrm{N}$ ratio associated with a decrease in ${ }^{13} \mathrm{C}$ toward the top of the core. This is probably related to the activity of either chemosynthetic bivalves or microbs which recycle organic matter or organic fluids $\left(\mathrm{CH}_{4}\right)$ and produce depleted ${ }^{13} \mathrm{C}$ and nitrogen-rich molecules from these sources. A tentative to evaluate this recycling of organic matter by benthic macrofauna in these habitats is presented in this special issue (Pruski et al., this volume).

\subsection{Processes responsible for homogeneous distribution of organic matter in the lobe complex}

Turbidite emplacement is by nature discontinuous and generates layers of sediment in which organic matter quantity, type and state of preservation are usually heterogeneous (Biscara et al., 2011; Caja and Permanyer, 2008; McArthur et al., 2016a, 2016b; Meyers et al., 1996; Saller et al., 2006; Watanabe and Akiyama, 1998). This is not the case in the Congo mud-rich turbidite system, in which the organic matter distribution appears very homogeneous. This has been previously demonstrated in the channel-levee systems of the Congo deep-sea fan, at 150 to $250 \mathrm{~km}$ upstream from the entrance of the lobe complex (Baudin et al., 2010). The present study confirms that this homogeneity also characterizes the terminal lobe complex. According to the Rock-Eval pyrolysis parameters, the TOC shows more or less a constant quantity ( 3.5 to $4 \%$ ) and quality whatever the studied scale, 
from the single turbidite to several metre-long successions. This homogeneity is due to the fine grain composition of lobe sediments, mainly composed by clay and fine silt fractions.

On the one hand, Spencer et al. (2012) reported that the fine suspended sediment $(<63 \mu \mathrm{m})$ dominates the total suspended sediment load at the Malebo Pool along the Congo River, comprising $81-94 \%$ of the sediment load and containing between $7-8.8 \%$ of Corg. We can assume that the same proportion of fine particulate organic matter reaches the estuary and constitutes the main organic fraction in the turbidity currents. After a $1250 \mathrm{~km}$-long travel (following the meanders of the Congo submarine valley), turbidity currents stop and build the terminal lobes with still a high proportion of organic matter particles associated with fine-grain component of the sediment. The sorting which usually characterizes turbidite event has little impact here as the sediment building the levees is very homogeneous and mainly composed of silt and clays. In sandier turbidite systems, such as the Ogooué turbiditic system (Biscara et al., 2011) or the Mahakam system (Huc et al., 2001; Saller et al., 2006), large woody fragments are mixed with the sand fraction and cuticles are usually concentrated in the topmost layers of turbidite deposits, because of their buoyancy. In the Congo turbidite system, such a particulate sorting is limited because most of the exported organic material is very fine. On the other hand, the homogeneity of organic matter distribution in the lobe complex may also be related to post-depositional mixing. Indeed, many erosional structures, such as collapsed blocks and scours, were observed at $5000 \mathrm{~m}$ water-depth all over the lobe complex (Dennielou et al., this volume). This proves that some turbidity currents are powerful enough to rework and erode the seafloor. The resulting reworking may redistribute the sediment -including its organic fraction- and possibly erase a primary lithological and organic contrast at the scale of individual turbidite. As the organic matter reaching the lobe complex is prominently refractory, a reworking has a limited effect on its quality, and even may contribute to the recycling of the labile fraction initially preserved.

This labile fraction of organic matter in the sediment partly comes from the riverine source and partly from the sea-surface export production, although the latter is very limited within the lobe 
area. According to the flux measured at site A during the 10 month mooring between the WACS and Congolobe cruises, about $1.2 \mathrm{~g} \mathrm{C} / \mathrm{m}^{2} . \mathrm{yr}^{-1}$ reach the seafloor (Alexis Khripounoff, pers. comm.). This flux represents less than $1 \%$ of the organic carbon produced in the sea-surface waters and is negligible compared to the carbon flux related to turbiditic events. According to the high sedimentation rate measured in the lobe complex and the richness in organic matter of sediments, the marine particles settling from the surface are a minor contribution to the sediment.

This marine organic matter shows higher $\mathrm{HI}$ values and lower Ol values than the terrestrial organic matter (Fig. 10), suggesting that it is still reactive. If we compare the Rock-Eval signature of trapped sediment and hemipelagic sediment from sites $E$ or $D$, it clearly appears that this marine flux is intensely remineralized. In fact, marine organic matter is deeply and rapidly altered throughout the water column and after deposition in the first centimetres of the sediment as shown by Treignier et al. (2006) on the $n$-alcohol fraction and Stetten et al. (submitted) on the fatty-acid fraction. As already mentioned, the topmost layer $(1$ to $2 \mathrm{~cm}$ ) of sediment is subject to various processes (erosion, diffusion, early diagenesis, bioturbation) before its final incorporation in the sedimentary column. This probably explains the decrease of TOC contents and the increase of OI values recorded in the MTB cores (Fig. 4). The reason of the disappearance of this layer with depth is unclear. It may be postulated that this reactive and fluffy layer is washed away and cannot be preserved when denser particles settle rapidly as soon as a turbiditic event occurs. These lighter particles remain longer in suspension before being redeposited. Finally, they are more altered and slowly incorporated into the sediment.

All the above-mentioned physical and chemical processes contribute to the good preservation and homogenisation of riverine-derived organic matter in the terminal lobe complex of the Congo deepsea fan. Although bulk proxies and Rock-Eval data highlight the general uniformity of the organic matter preserved in the terminal lobe complex, the organic fraction appears more heterogeneous when looking at molecular level (Méjanelle et al, this volume; Stetten et al., submitted). 
Despite the general homogeneity and as mentioned in the result chapter, a slight increasing trend of TOC (+ $0.5 \%$ on average) is noted in background sediments from the proximal site $A$ to the distal site C (Fig. 12). This slight increase can be explained by the fact that the sedimentary inputs at site $C$ are the most recent and have the highest sedimentation rate, thus allowing a better preservation of organic matter. Moreover, an increase in organic matter supply from the Congo River during the last tens of years cannot be ruled out.

\subsection{Implication for organic matter accumulation in the deep sea}

The good preservation of terrestrial organic matter is also related to exceptionally high sedimentation rates in the terminal lobe complex of the Congo deep-sea fan. Extremely high sedimentation rates were noticed in the filling of the channel at site $C$ (up to $10-22 \mathrm{~cm}$. $\mathrm{yr}^{-1}$; Rabouille et al., this volume; Stetten et al., 2015), whereas in levee sediments at sites A and B, the sedimentation rate is still high ( 0.6 to $\left.1 \mathrm{~cm} . \mathrm{yr}^{-1}\right)$. Such values are several orders of magnitude higher than sedimentation rate in the deep area of the Gulf of Guinea where values ranging from 2-8 $\mathrm{cm} . \mathrm{kyr}^{-1}$ were reported for the Holocene (Mollenhauer et al., 2004). Thus, the sedimentation rates in the active lobes of the Congo deep-sea fan are 100 to 1000 times larger in the levees and infilling of the active channel (Site $\mathrm{C}$ ) than the surrounding abyssal plains.

As these deposits are organic rich, the lobe complex of the Congo deep-sea fan clearly represents a substantial sink for organic matter in that part of the Atlantic Ocean. A similar conclusion was inferred from the study of the channel-levee systems, several hundred kilometres upstream, near 4000 m-depth (Baudin et al., 2010). The sedimentation rate in the channel-levee systems varies from 25 to $400 \mathrm{~cm} \cdot \mathrm{kyr}^{-1}$, which is still one to two orders of magnitude higher than sedimentation rate in the abyssal plain. Together the channel-levee systems and lobe complexes of the Congo deep-sea fan represent an important sink for terrestrial organic matter. An assessment of the final quantity of organic carbon stored in the entire turbidite system needs i) a volumetric estimation of channel, levee and lobe and ii) a better chronostratigraphic allocation of the deposits. Recently, Picot (2015) estimated that the volume of the lobe complex investigated by the WACS and Congolobe cruises is 
approximately $90 \mathrm{~km}^{3}$. Taking a TOC average of $3.5 \%$ in lobe sediments and an averaged density of 1.6 for muddy sediments, we calculate that approximately $5 \mathrm{Gt} \mathrm{C}$ are accumulated in the entire lobe complex. Assuming that the building of the present-day active lobe complex started 4 kyr ago (Picot, 2015), the mean yearly storage of organic carbon in the lobe complex is approximately $1.25 \mathrm{Mt}$, three times higher than the sink estimated by Rabouille et al. (2009) on the same area. Despite our roughly assumptions, we can consider that both estimations are in the same range and the magnitude is probably correct.

Other examples of active turbidite systems prone to the storage of terrestrial organic matter are not frequent. The Congo deep-sea turbidite system is one of the largest in the world still affected by turbidite sedimentation during the interglacial high sea-level (Savoye et al., 2000). Such a phenomenon is unique along the present-day African margin as most of the canyons are not directly connected with the associated river. The Ogooué turbidite system, however, presents some similarities with the Congo system with high organic matter contents and high sedimentation rates (Biscara et al., 2012; Fig. 13).

During the glacial periods, when sea-level was low, other large rivers, including the Amazon River, were directly connected to their submarine canyons and carbon transfer from land to the deep-sea was much higher than today. However, the organic richness of Amazon turbidite sediments and the accumulation rate during the low-stand sea-level glacial periods are lower compared to the Congo system (Fig. 13). This is also the case of the Bengal fan with lower TOC contents ( $0.5 \%$ in average) and lower sedimentation rates, at least where data are available. A comparison of selected organic-rich turbidite systems (Table 3, Fig. 13) demonstrates that the Congo deep-sea fan is exceptional compared to other deep-sea turbidite systems. This is probably due to the high proportion of organic matter in the suspended material delivered by the Congo River compared to others (1/25 against 1/50 or 1/100 for Amazon and Bengal respectively; Meybeck, 1993; Seiter et al., 2004) and by the richness in clay fraction which is prone to adsorption of organic matter on their surface. 


\section{Conclusions}

Recent sediments from the terminal lobe complex of the Congo turbidite system were analyzed using Rock-Eval pyrolysis. This technique is a rapid and accurate tool to determine the quantity, source and state of degradation of organic matter that complements other interpretations based on elemental and isotopic analyses. The bulk organic characteristics of the lobe complex sediments are the following:

- Although collected in various environments (channel, levees, filling or erosive areas) with high but contrasted accumulation rates, sediments from sites A, F, C and B show similar organic characteristics. TOC contents are very homogeneous with a mean value around $3.5 \%$ in silty-muddy turbidite facies. However, a slight increase in the organic richness may be depicted from the proximal site $A$ to the distal site $C$.

- The hydrogen and oxygen indices measured in lobe sediments are consistent with the view that distal lobes of the Congo deep-sea-fan contain high amount of terrestrial organic matter. Confirming the previously published estimation based on $\mathrm{C} / \mathrm{N}$ and isotopic data, the nature of organic matter in the lobe complex is dominated ( $>80 \%$ ) by a terrestrial source containing a mixture of higher plant debris and soil derived organic matter. The Rock-Eval signature of sediments from the lobe complex and from the Congo River are similar, suggesting a limited degradation of the riverine suspended organic matter during its transfer to the deep-sea.

- When preserved by the coring-tool, the two first centimetres of sediment below the sediment/water interface are characterized by a decrease in TOC and an increase of the oxygen index parameter, suggesting active remineralization. The reason of the disappearance of this layer with depth is unclear, but it may be postulated that this reactive and fluffy layer is washed away and cannot be preserved as soon as a turbiditic event occurs. 
- Hemipelagic sediments collected at site $\mathrm{E}$-where the turbidite process is no more active since several thousands of years- and in the long core at site D show a lower TOC content, with values ranging from 0.2 to $1 \%$. The degradation of organic matter in such facies is also suggested by higher oxygen index values.

- Areas with chemosynthetic bivalves and/or bacterial mats, explored using ROV Victor 6000, show a Rock-Eval signature similar to background turbidite sediment as demonstrated by Rock-Eval, $\mathrm{C} / \mathrm{N}$ and isotopic data. Nevertheless, some exceptions occur. TOC contents in a black patch of reduced sediment are higher than in the background sediment, with values up to $5.4 \%$, suggesting a contribution of the bacterial biomass. By contrast, higher TOC contents in background sediment compared to the fringing zone of the vesicomyid habitats suggest an active recycling of organic matter by the benthic macrofauna. One vesicomyid habitat and a microbial mat show a general trend of decreasing $\mathrm{C} / \mathrm{N}$ ratio associated with a decrease in ${ }^{13} \mathrm{C}$ toward the top of the core. This is probably related to the activity of either chemosynthetic bivalves or microbes which produce isotopically-lighter and nitrogen-rich molecules from the available carbon sources.

- Considering the high sedimentation rates (1 to $\left.20 \mathrm{~cm} \cdot \mathrm{yr}^{-1}\right)$ determined at sites $A, B$ and $C$ and the high concentration of organic carbon in accumulated sediments, the $2500 \mathrm{~km}^{2}$ of active lobe complex represents an important sink for terrestrial organic carbon. If the long-term evolution of this system needs to consider the construction history of the Congo deep-sea fan, the centennial to millennial time scale can be apprehended here. Indeed, the terminal lobe complex, which represents $90 \mathrm{~km}^{3}$ of sediment deposited during the last $4 \mathrm{kyr}$, would have stored $1.2510^{6}$ tons of organic carbon.

- Compared to other large turbidite systems (e.g. Amazon or Bengal fans), the Congo turbidite system appears very efficient for organic matter storage, even during high-stand periods. This is obviously due to the direct connection of the river mouth to the deep ocean by the canyon but also to the high proportion of organic matter in the suspended material delivered 
by the Congo River compared to other worldwide rivers. A re-evaluation of other deep-sea fans as possible terrestrial organic matter sink during lowstand periods is needed.

\section{Acknowledgements -}

We are grateful to Ifremer/Genavir for the WACS and Congolobe campaigns onboard the R/V Pourquoi Pas? and K.Olu and C. Rabouille for leading the WACS and Congolobe campaigns respectively. We acknowledge Bruno Bombled, Solveig Bourgeois, Sabrina Lucas, Philippe Noël and Gilles Vétion for their participation in sampling during WACS and Congolobe campaigns. We thank Rob Spencer and Helen Talbot for providing samples from the Congo River. We are grateful to Florence Savignac, Anabel Aboussou and Jennifer Sorriaux for analytical help on the Rock-Eval apparatus. Nathalie Babonneau provided the background of figures 2 and 3, Alexis Khripounoff provided information of the mooring and Alexandre Lethiers improved all our rough drawings. We express our gratitude to Audrey Pruski and Laurence Mejanelle for fruitful discussions. Elsa Stetten was supported for her Ph-D by a doctoral grant from UPMC. Finally, we acknowledge Armelle Riboulleau, Alain-Yves Huc and two anonymous reviewers for their fruitful comments on earlier draft of this paper. This work was supported by the ANR grant Congolobe (ANR-11-BS56-0030, 60 20112015).

Supplementary Table 1 - Rock-Eval data for all samples analyzed in the present study Supplementary Table $2-\delta^{13} \mathrm{C}_{\text {org }}$ and $\mathrm{C} / \mathrm{N}$ data on ROV core samples

\section{References}

Babonneau, N., 2002. Mode de fonctionnement d'un chenal turbiditique méandriforme: Cas du système turbiditique actuel du Zaïre. Thèse de doctorat, Université de Bordeaux I, 308 p. 
Babonneau, N., Savoye, B., Cremer, M., Bez, M., 2010. Sedimentary Architecture in Meanders of a Submarine Channel: Detailed Study of the Present Congo Turbidite Channel (Zaiango Project). J. Sed. Res. 80, 852-866.

Babonneau, N., Savoye, B., Cremer, M., Klein, B., 2002. Morphology and architecture of the present canyon and channel system of the Zaire deep-sea fan. Mar. Petrol. Geol. 19, 445-467.

Baudin, F., Disnar, J.R., Aboussou, A., Savignac, F., 2015. Guidelines for Rock-Eval analysis of recent marine sediments. Organic Geochemistry, 86, 71-80.

Baudin, F., Disnar, J.R., Martinez, P., Dennielou, B., 2010. Distribution of the organic matter in the channel-levees systems of the Congo mud-rich deep sea fan (West Africa). Implication for deep offshore petroleum source rocks and global carbon cycle. Mar. Petrol. Geol. 27, 995-1010.

Behar, F., Beaumont, V., de Penteado, B.H.L., 2001. Rock-Eval 6 Technology: Performances and Developments. Oil \& Gas Science and Technology - Rev. IFP, 56, 2, 111-134.

Benner, R., 2004. What happens to terrestrial organic matter in the ocean? Mar.Chem., 92, 307-310.

Berner, R.A, 1982. Burial of organic-carbon and pyrite sulfur in the modern ocean - its geochemical and environmental significance. American Journal of Science, 282, 4, 451-473.

Bianchi, T.S., Allison, M.A., Cai, W.J., 2014. An introduction to the biogeochemistry of river-coastal systems. In Biogeochemical dynamics at Major River-Coastal Interfaces Linkages with Global Change (eds. T.S. Bianchi, M.A. Allison and W.J. Cai) Cambridge Univ. Press, 3-18.

Biscara, L., Mulder, T., Martinez, P., Baudin, F., Etcheber, H., Jouanneau, J.M., Garlan, T., 2011. Transport of terrestrial organic matter in the Ogooué deep sea turbidite system (Gabon). Marine and Petroleum Geology 28, 1061-1072.

Blair, N.E., Aller, R.C., 2012. The fate of terrestrial organic carbon in the marine environment. Annu. Rev. Mar. Sci. 4, 401-423.

Bonnel, C., 2005. Mise en place des lobes distaux dans les systèmes turbiditiques actuels : Analyse comparée des systèmes du Zaïre, Var et Rhône. Thèse de doctorat, Université de Bordeaux I, $275 \mathrm{p}$. 
Burdige, D.J., 2005. Burial of terrestrial organic matter in marine sediments; a re-assessment. Global Biogeochemical Cycles. 19, 4, GB4011, doi:10.1029/2004GB002368.

Cadée, G.C., 1984. Particulate and dissolved organic carbon and chlorophyll a in the Zaire River, estuary and plume. Neth. J. Sea Res. 17, 426-440.

Caja, M.A., Permanyer, A., 2008. Significance of organic matter in Eocene turbidite sediments (SE Pyrenees, Spain). Naturwissenschaften, 95, 1073-1077.

Carrie, J., Sanei, H., Stern, G., 2012. Standardisation of Rock-Eval pyrolysis for the analysis of recent sediments and soils. Organic Geochemistry 46, 38-53.

Coynel, A., Seyler P., Etcheber H., Meybeck M., Orange D., 2005. Spatial and seasonal dynamics of total suspended sediment and organic carbon species in the Congo River. Global Biogeochem. Cycles 19, 4, 17 p. doi:10.1029/2004GB002335

Croguennec C., Ruffine L., Dennielou B., Baudin F., Caprais J.-C., Guyader V., Bayon G., Brandily C., Le Bruchec J., Bollinger C., Germain Y., Droz L., Babonneau N., Rabouille C., this volume. Evidence and age estimation of mass wasting at the distal lobe of the Congo deep-sea fan. Deep Sea Research Part II: Topical Studies in Oceanography, Special volume Congolobe

Curray, J.R., Emmel, F.J., Moore, D.G., 2003. The Bengal Fan: morphology, geometry, stratigraphy, history and processes. Marine and Petroleum Geology, 19, 1191-1223.

Dagg, M., Benner, R., Lohrenz, S., Lawrence, D., 2004. Transformation of dissolved and particulate materials on continental shelves influenced by large rivers: plume processes. Contin. Shelf Res. $24,833-858$.

Dahl, B., Bojesen-Koefoed, J., Holm, A., Justwana H., Rasmussen, E., Thomsen, E., 2004. A new approach to interpreting Rock-Eval S-2 and TOC data for kerogen quality assessment. Organic Geochemistry, 35, 11-12, 1461-1477.

Degens, E.T., Kempe, S., Richey, J.E., 1991. Summary: biogeochemistry of major world rivers in: Degens, E.T., Kempe, S., Richey, J.E. (Eds.), Biogeochemistry of major world rivers. Wiley and sons, Chichester, pp. 323-348. 
Dennielou B., Droz L., Jacq C., Babonneau N., Bonnel C., Picot M., Le Saout M., Saout J. Bez M., Savoye B. Olu K., Rabouille C., this volume . Morphology, structure, composition and build-up processes of the active Congo channel-mouth lobe complex with inputs from remotely operated underwater vehicle (ROV) multibeam and video surveys. Deep Sea Research Part II: Topical Studies in Oceanography, Special volume Congolobe

Droz, L., Marsset, T., Ondreas, H., Lopez, M., Savoye, B., Spy-Anderson, L., 2003. Architecture of an active mud-rich turbidite system: the Zaire Fan (Congo-Angola margin southeast Atlantic). Results from Zaiango 1 and 2 cruises, 87(7): AAPG Bulletin 87, 1145-1168.

Droz L., Rigaut F., Cochonat P., Tofani R., 1996. Morphology and recent evolution of the Zaire turbidite system (Gulf of Guinea). Geol. Soc. Am. Bull., 108, 253-269.

Durand, B., 1980. Kerogens, Insoluble Organic Matter from Sedimentary Rocks. Technip, Paris.

Eisma, D., Kalf J., 1984. Dispersal of Zaire River suspended matter in the estuary and the Angola basin. Netherlands Journal of Sea Research, 17, 2-4, 385-411.

Espitalié, J., Laporte, J.L., Madec, M., Marquis, F., Leplat, P., Paulet, J., 1977. Méthode rapide de caractérisation des roches mères, de leur potentiel pétrolier et de leur degré d'évolution. Revue de l'Institut Français du Pétrole 32, 23-45.

Espitalié, J., Deroo, G., Marquis, F. 1985. La pyrolyse Rock-Eval et ses applications. Partie I. Rev. Inst. Fr. Pétrole, 40/5, 563-579.

Galy, V., France-Lanord, C., Beyssac, O., Faure, P., Kudrass, H., Plahol, F., 2007. Efficient organic carbon burial in the Bengal fan sustained by the Himalayan erosional system. Nature, 450, 407411.

Goni, M.A., Ruttenberg, K.C., Eglinton, T.I., 1997. Sources and contribution of terrigenous organic carbon to surface sediments in the Gulf of Mexico. Nature 389, 275-278.

Hedges, J.I., Keil, R.G., 1995. Sedimentary organic-matter preservation an assessment and speculative synthesis. Mar. Chem. 49, 81-115. 
Hedges, J.I., Keil, R.G., Benner, R., 1997. What happens to terrestrial organic matter in the ocean? Org. Geochem. 27, 195-212.

Heezen, B.C., Menzies, R.J., Schneider, E.D., Ewing, W.M., Granelli, N.C.L., 1964. Congo Submarine Canyon. AAPG Bulletin 48, 1126-1149.

Hinrich K.-U., Summons R.E., Orphan V., Sylva S.P., Hayes J.M., 2000. Molecular and isotopic analysis of anaerobic methane-oxidizing communities in marine sediments. Org. Geochem., 31, 16851701.

Huc, A.Y., Bertrand, P., Stow, D.A.V., Gayet, J., Vandenbroucke, M., 2001. Organic sedimentation in deep offshore settings: the Quaternary sediments approach. Mar. Petrol. Geol., 18, 513-517.

Jansen, J.H.F., Van Weering, T.C.E., Gieles, R. and Van Iperen, J., 1984. Middle and Late Quaternary oceanography and climatology of the Zaire-Congo fan and adjacent eastern Angola Basin. Netherlands Journal of Sea Research, 17(2-4): 201-249

Khripounoff, A., Vangriesheim, A., Babonneau, N., Crassous, P., Savoye, B., Dennielou, B., 2003. Direct observation of intense turbidity current activity in the Zaire submarine valley at $4000 \mathrm{~m}$ water depth. Mar. Geol. 194, 151-158.

Kinga-Mouzéo, M., 1986. Transport particulaire actuel du fleuve Congo et de quelques affluents : enregistrement quaternaire dans l'éventail détritique profond (sédimentologie, minéralogie et géochimie), Thèse de doctorat, Université de Perpignan, $261 \mathrm{p}$.

Lafargue, E., Marquis, F., Pillot, D., 1998. Rock-Eval 6 Applications in Hydrocarbon Exploration, Production and Soils Contamination Studies. Oil \& Gas Science and Technology- Rev. IFP, 53, 4, 421-437.

Langford, F.F., Blanc-Valleron, M.M., 1990. Interpreting rock-eval data using graphs of pyrolizable hydrocarbons vs. total organic carbon. AAPG Bulletin 74 (6), 799-804.

Laraque, A., Bricquet, J.P., Pandi, A., Olivry, J.C., 2009. A review of material transport by the Congo River and its tributaries. Hydrol. Process. 23, 3216-3224. 
Ludwig, W., Amiotte-Suchet, P., Probst, J.L., 1996. River discharges of carbon to the world's oceans: determining local inputs of alkalinity and of dissolved and particulate organic carbon. C.R. Acad. Sciences, 323, 12, 1007-1014.

Mariotti, A., Gadel, F., Giresse, P., Kinga-Mouzéo, M., 1991. Carbon isotope composition and geochemistry of particulate organic matter in the Congo River (Central Africa): application to the study of Quaternary sediments off the mouth of the river. Chem. Geol., 86, 345-357.

Marsset, T., Droz, L., Dennielou, B., Pichon, E., 2009. Cycles in the architecture of the Quaternary Zaire turbidite system: a possible link with climate, in: Kneller, B. (Ed.), External Controls on Deep-Water Depositional Systems. SEPM Special Publication, pp. 89-106.

McArthur A.D., Kneller B.C., Souza P.A., Kuchle J., 2016a. Characterization of deep-marine channellevee complex architecture with palynofacies: An outcrop example from the Rosario Formation, Baja California, Mexico. Mar. Petrol. Geol., 73, 157-173.

McArthur A.D., Kneller B.C., Wakefield M.I., Kuchle J., 2016b. Palynofacies classification of the depositional elements of confined turbidite systems: Examples from the Gres d'Annot, SE France. Mar. Petrol. Geol., 77, 1254-1273.

Méjanelle L., Rivière B., Pinturier L., Khripounoff K., Baudin F., Dachs J., this volume. Aliphatic hydrocarbons and triterpenes of the Congo deep sea fan. Deep Sea Research Part II: Topical Studies in Oceanography, Special volume Congolobe

Meybeck, M., 1993. Riverine transport of atmospheric carbon - sources, global typology and budget. Water Air and Soil Pollution, 70, 1-4, 443-463.

Meyers, P.A., Silliman, J., Shaw, T.J., 1996. Effects of turbidity flows on organic matter accumulation, sulfate reduction, and methane generation in deep-sea sediments on the Iberia Abyssal Plain. Org. Geochem. 25, 1-2, 69-78.

Migeon, S., Savoye, B., Babonneau, N., Spy Andersson, F.-L., 2004. Processes of sediment-wave construction along the present-day Zaire deep-sea meandering channel: role of meanders and flow stripping. J. Sedim. Res. 74 (4), 580-598. 
Mollenhauer, G., Schneider, R.R., Jennerjahn, T., Muller, P.J. and Wefer, G., 2004. Organic carbon accumulation in the South Atlantic Ocean: its modern, mid-Holocene and last glacial distribution. Glob. Planet. Change 40, 249-266.

N’kounkou, R.R., Probst, J.L., 1987. Hydrology and geochemistry of the Congo River system, in Transport of Carbon and Minerals in Major World Rivers, vol. 64, edited by E. T. Degens, S. Kempe, and W. B. Gan, Mitt. Geol.-Paläont. Inst., Univ. Hamburg, 483-508.

Olu K., 2011. WACS cruise, Pourquoi Pas? R/V, http://dx.doi.org/10.17600/11030010

Pak, H., Zaneveld, J.RV, Spinrad, R.W., 1984. Vertical-distribution of suspended particulate matter in the Zaire River, estuary and plume. Netherlands Journal of Sea Research, 17, 2-4, 412-425.

Pastor L., Toffin L., Decker C., Olu K., Cathalot C., Lesongeur F., Caprais J.-C., Bessette S., Brandily C., Taillefert M., Rabouille C., this volume. Early diagenesis in the sediments of the Congo deepsea fan dominated by massive terrigenous deposits: Part III - Sulfate- and methane- based microbial processes. Deep Sea Research Part II: Topical Studies in Oceanography, Special volume Congolobe

Peters, K.E., 1986. Guidelines for evaluating petroleum source rock using programmed pyrolysis. American Association of Petroleum Geologists Bulletin. 70, 318-329.

Picot, M., 2015. Cycles sédimentaires dans le système turbiditique du Congo : nature et origine. Thèse de doctorat, Université de Bretagne occidentale, 368 p.

Picot, M., Droz, L., Marsset, T., Dennielou, B., Bez, M., 2016. Controls on turbidite sedimentation: insights from a quantitative approach of channels and lobes architectural parameters (Late Quaternary Congo fan), Mar. Petrol. Geol., 72, 423-446.

Pruski A.M., Decker C., Stetten E., Vétion G., Martinez P., Charlier K., Senyarich C., Olu K.., this volume. Energy transfer in the Congo turbiditic system: from terrestrially-derived organic matter to chemosynthetic food webs. Deep Sea Research Part II: Topical Studies in Oceanography, Special volume Congolobe

Rabouille C., 2011. CONGOLOBE cruise, Pourquoi Pas? R/V, http://dx.doi.org/10.17600/11030170 
Rabouille, C., Caprais, J.C., Lansard, B., Crassous, P., Dedieu, K., Reyss, J.L., Khripounoff, A., 2009. Organic matter budget in the Southeast Atlantic continental margin close to the Congo Canyon: In situ measurements of sediment oxygen consumption. Deep-Sea Res. Part II-Top. Stud. Oceanogr. 56, 2223-2238

Rabouille C., Olu K., Baudin F., Khripounoff A., Dennielou B., Arnaud-Haond S., Babonneau N., Bayle C., Beckler J., Bessette S., Bombled B., Bourgeois S., Brandily C., Caprais JC., Cathalot C., Charlier K., Corvaisier R., Croguennec C., Cruaud P., Decker C., Droz L., Gayet N., Godfroy A., Hourdez S., Le Bruchec J., Le Saout J., Lesaout M., Lesongeur F., Martinez P., Mejanelle L., Michalopoulos P., Mouchel O., Noel P., Pastor L., Picot M., Pignet P., Pozzato L., Pruski AM., Rabiller M., Raimonet M., Ragueneau O., Reyss JL., Rodier P., Ruesch B., Ruffine L., Savignac F., Senyarich C., Schnyder J., Sen A., Stetten E., Sun M.Y., Taillefert M., Teixeira S., TisneratLaborde N., Toffin L., Tourolle J., Toussaint F., Vetion G., Jouanneau JM., Bez M., 2016. The Congolobe project, a multidisciplinary study of Congo deep-sea fan lobe complex: Overview of methods, strategies, observations and sampling. Deep Sea Research Part II: Topical Studies in Oceanography, Special volume Congolobe doi: 10.1016/j.dsr2.2016.05.006i

Saller, A., Lin, R., Dunham, J., 2006. Leaves in turbidite sands: the main source of oil and gas in the deep-water Kutei Basin, Indonesia. AAPG Bull., 90, 1585-1608.

Savoye, B., Babonneau, N., Dennielou, B., Bez, M., 2009. Geological overview of the Angola-Congo margin, the Congo deep-sea fan and its submarine valleys. Deep-Sea Res. Part II-Top. Stud. Oceanogr. 56, 2169.

Savoye, B., Cochonat, P., Apprioual, R., Bain, O., Baltzer, A., Bellec, V., Beuzart, P., Bourillet, J., Cagna, R., Cremer, M., Crusson, A., Dennielou, B., Diebler, D., Droz, L., Ennes, J., Floch, G., Foucher, J., Guiomar, M., Harmegnies, F., Kerbrat, R., Klein, B., Khun, H., Landure, J., Lasnier, C., Le Drezen, E., Le Formal, J., Lopez, M., Loubrieu, B., Marsset, T., Migeon, S., Normand, A., Nouze, H., Ondreas, H., Pelleau, P., Saget, P., Seranne, M., Sibuet, J.C., Tofani, R., Voisset, M., 2000. Structure et évolution récente de l'éventail turbiditique du Zaïre: Premiers résultats 
scientifiques des missions d'exploration ZaiAngo 1 and 2 (Marge Congo-Angola). C. R. Acad. Sci. Paris 311, 211-220.

Seiter, K., Hensen, C., Schroter, E., Zabel, M., 2004. Organic carbon content in surface sediments defining regional provinces. Deep-Sea Research Part I-Oceanographic Research Papers, 51, 12, 2001-2026.

Schlünz, B., Schneider, E.D., Muller, P.J., Showers, W.J., Wefer, G., 1999. Terrestrial organic carbon accumulation on the Amazon deep-sea fan during the last glacial sea level low stand. Chem. Geol. 159, 263-281.

Schlünz, B., Schneider, R.R., 2000. Transport and terrestrial organic carbon to the oceans by rivers: re-estimating flux and burial rates. Int. J. Earth Sci. 88, 599-606.

Schnyder J., Stetten E., Baudin F., Pruski A., Martinez P., this volume. Palynofacies reveal fresh terrestrial organic matter inputs in the terminal lobes of the Congo deep-sea fan. Deep Sea Research Part II: Topical Studies in Oceanography, Special volume Congolobe Spencer, R.G.M., Hernes, P.J., Aufdenkampe, A.K., Baker, A., Gulliver, P., Stubbins, A., Aiken, G.R., Dyda, R.Y., Butler, K.D., Mwamba, V.L., Mangangu, A.M., Wabakanghanzi, J.N., Six, J., 2012. An initial investigation into the organic matter biogeochemistry of the Congo River. Geochim. Cosmochim. Acta 84, 614-627.

Spencer, R.G.M., Stubbins, A., Gaillardet, J., 2014. Geochemistry of the Congo River, estuary and plume. In Biogeochemical dynamics at Major River-Coastal Interfaces Linkages with Global Change (eds. T. S. Bianchi., M. A. Allison. and W. J. Cai). Cambridge Univ. Press, Cambridge. pp. 3-18.

Stetten, E., Baudin F., Huguet, A., Vetion, G., Haolin, W., Senyarich C., Sun, M.Y., Culp, R., Pruski. A., submitted. Organic matter sources and preservation in sediments from the terminal lobe complex of the Congo deep-sea fan: new insights from lipid biomarkers and isotope signatures of fatty acids. Submitted GCA. 
Stetten, E., Baudin, F., Reyss, J.L., Martinez, P., Charlier, K., Schnyder, J., Rabouille, C., Dennielou, B., Coston-Guarini, J., Pruski, A., 2015. Organic matter characterization and distribution in sediments of the terminal lobes of the Congo deep-sea fan: evidence for the direct influence of the Congo River. Mar. Geol. 369, 182-195.

Talbot, H.M., Handley, L., Spencer-Jones, C.L., Bienvenue, D.J., Schefuss, E., Mann, P.J., Poulsen, J.R., Spencer, R.G.M., Wabakanghanzi, J.N., Wagner, T., 2014. Variability in aerobic methane oxidation over the past 1.2 Myrs recorded in microbial biomarker signatures from Congo fan sediments. Geochim. Cosmochim. Acta 133, 387-401.

Tissot, B.P., Welte, D.H. 1984. Petroleum formation and occurrence. Springer, Berlin. 699 p.

Treignier, C., Derenne, S., Saliot, A., 2006. Terrestrial and marine n-alcohol inputs and degradation processes relating to a sudden turbidity current in the Zaire canyon. Org. Geochem. 37, 11701184.

van Weering, T.C.E., van Iperen, J., 1984. Fine-grained sediments of the Zaire deep-sea fan, southern Atlantic Ocean. Geol. Soc. Lond. Spec. Publ. 15, 95-113.

van Weering, T.C.E., de Stigter, H.C., Boer, W., de Haas, H., 2002. Recent sediment transport and accumulation on the NW Iberian margin. Progress in Oceanography, 52, 349-371.

Vangriesheim, A., Khripounoff, A., Crassous, P., 2009. Turbidity events observed in situ along the Congo submarine channel. Deep-Sea Res. Part II-Top. Stud. Oceanogr. 56, 2208-2222.

Watanabe, H., Akiyama, M., 1998. Characterization of organic matter in the Miocene turbidites and hemipelagic mudstones in the Niigata oil field, central Japan. Org. Geochem. 29, 1-3, 605-611. Wetzel, A., 1993. The transfer of river load to deep-sea fans: a quantitative approach. AAPG Bull., 77, 1679-1692. 
Fig. $1-A)$ 3D view of the bathymetric map off the Congo River mouth showing the deep-sea fan turbidite system with the present-day unique active channel which ends as a distal lobe complex (reprint from Savoye et al., 2009). B) General bathymetric map of the distal lobe complex of the Congo turbidite system with location of the 6 sites explored during WACS and Congolobe campaigns. The lobe complex shows a series of lobes (labelled 1 to 5 from the oldest to the youngest) having a grape-like prograding downstream organization. Boundaries of the lobe complex and its subdivision are simplified from Babonneau (2002).

Fig. 2 - Views of the sea-floor sediments with sampling sites into chemosynthetic habitats explored using ROV Victor 6000 during WACS and Congolobe campaigns. Refer to Table 1 and Fig. 1B for the site location. (C) Ifremer/WACS or Congolobe for all photographs. a) WACS-A-PL435-CT08 core was recovered at the border of a vesicomyid habitat of site A. b) Possible microbial mats sampled by WACS-C-PL436-CT11 core. c) Fringe of the mouth-shape vesicomyid habitat sampled by core WACSC-PL437-CT02. d) A heart-shape vesicomyd habitat with location of the 3 studied cores (CoL-C-PL491СТ01, 05 and 14). e) A large black patch of reduced sediment with location of the 2 studied cores (CoL-C-PL490-CT13 and 15). f) Hemipelagic sediment with tubular agglutinated foraminiferal genus Bathysiphon sampled by two pushcores (WACS-D-PL438-CT02 and 05).

Fig. 3 - Core logs showing the lithological changes and vertical distribution of Total Organic Carbon (TOC, in wt\%), Hydrogen Index ( $\mathrm{HI}$ ) and Oxygen Index (OI ) of the six gravity-cores studied in different parts of the terminal lobe complex of the Congo deep-sea fan. The map showing the architecture of the lobe complex is reprinted from Babonneau (2002).

Fig. 4 - Vertical distribution of the granulometric composition of the sediment, Total Organic Carbon (TOC, in wt\%), Hydrogen Index ( $\mathrm{HI}$ ) and Oxygen Index (OI ) of the nine multitube-cores studied in 
different parts of the terminal lobe complex of the Congo deep-sea fan. Refer to Fig. 3 for legends of the architecture of the lobe complex.

Fig. 5 - Vertical evolution of selected Rock-Eval parameters measured on four CT cores recovered in black patches of reduced sediment at site C (see Fig. 2e). TOC: Total organic carbon content (in wt\%), HI: hydrogen index, OI: oxygen index. The aspect of the sediment of core CoL-C- PL490-CT13 is shown on the right.

Fig. 6 - Vertical evolution of selected Rock-Eval parameters, $\delta^{13} C_{\text {org }}$ and $C / N$ ratios measured in a CT core (WACS-C-PL436-CT11) recovered in black and white microbial mat at site C by the ROV tubecorer (see Fig. 2b). TOC: Total organic carbon content (in wt\%), HI: hydrogen index, OI: oxygen index.

Fig. 7 - Vertical evolution of selected Rock-Eval parameters, $\delta^{13} \mathrm{C}_{\text {org }}$ and $\mathrm{C} / \mathrm{N}$ ratios measured on one $\mathrm{CT}$ core recovered at the fringe of vesicomyid habitats at site A (Fig. 2a) and two cores from site C (see Fig. 2c), all of them collected by the ROV tube-corer. The grey tape indicates the penetrationdepth of vesicomyids. TOC: Total organic carbon content (in wt\%), HI: hydrogen index, Ol: oxygen index.

Fig. 8 - Vertical evolution of selected Rock-Eval parameters, $\delta^{13} \mathrm{C}_{\text {org }}$ and $\mathrm{C} / \mathrm{N}$ ratios measured on three CT cores recovered in the heart-shape vesicomyid habitat at site $\mathrm{C}$. The grey line indicates the penetration-depth of vesicomyid. TOC: Total organic carbon content (in wt\%), HI: hydrogen index, OI: oxygen index. The aspect of the sediment of two cores is shown on the right. Note that the vesicomyid bivalve specimen recovered within core CT15 at 7-10 $\mathrm{cm}$ depth was probably pushed from the surface during penetration. 
Fig. 9 - Vertical evolution of selected Rock-Eval parameters, $\delta^{13} \mathrm{C}_{\mathrm{org}}$ and $\mathrm{C} / \mathrm{N}$ ratios measured on one CT core (WACS-D- PL438-CT02) recovered at site D (see Fig. 2f). TOC: Total organic carbon content (in wt\%), HI: hydrogen index, Ol: oxygen index.

Fig. 10-Kerogen type in the silty-clayey sediments of the lobe complex of the Congo deep-sea fan as defined by (A) the cross-plot of TOC and S2 Rock-Eval parameters and (B) a modified van Krevelen diagram (HI-OI). Nearly all samples are located in the domain of Type III kerogen which usually derives from higher-plant debris. Samples with high OI-values correspond to hemipelagic samples from site $D$ and $E$ in which the organic matter is strongly oxidized. The Rock-Eval signature of samples from i) sediment trap of site A, ii) Congo River (bedload, bank and floodplain) samples collected near Kinshasa and iii) pure biomolecules and plant fragments (data from Carrie et al., 2012) are reported on the cross-plots.

Fig. $11-\mathrm{C} / \mathrm{N}$ versus $\delta^{13} \mathrm{C}_{\text {org }}$ cross-plot of sediment samples from selected chemiosynthetic habitats studied during WACS and Congolobe campaigns. Data of MTB samples from Stetten et al. (2015) show the elemental and isotopic signature of the background sediment.

Fig. 12 - Averaged Total Organic carbon (TOC) content in MTB and CS cores studied in different sites of the terminal lobe complex of the Congo deep-sea fan. A slight increase in TOC is noted along the active channel from site $A$ to site $C$, whereas a sharp decrease is noted in hemipelagic facies when moving away from the channel.

Fig. 13 - Relationship between Corg concentration and sedimentation rate in deep marine environments supplied by pelagic settling (black symbols) compared to examples of deep marine environments supplied by turbidite systems (red and blue symbols). See Table 3 for the data and references of sedimentation rate and \%Corg of the turbidite systems reported here. 
Table 1 - Designation, type, geographic data, depth and sedimentological context of the cores analyzed in this study (refer to Fig. 1B for the location of sites A to F). The penetration of each core (in $\mathrm{cm}$ below sea-floor), the studied interval and the number of samples analyzed are given in the last columns. A total of 473 core-samples were selected and analyzed for this study.

\begin{tabular}{|c|c|c|c|c|c|c|c|c|c|}
\hline $\begin{array}{c}\text { Sit } \\
\mathrm{e}\end{array}$ & Context & $\begin{array}{l}\text { Core } \\
\text { type }\end{array}$ & $\begin{array}{l}\text { Core } \\
\text { numbe } \\
r\end{array}$ & Lat. ${ }^{\circ} \mathrm{S}$ & Long. ${ }^{\circ} \mathrm{E}$ & $\begin{array}{c}\text { Water } \\
- \\
\text { depth } \\
\text { (m) }\end{array}$ & $\begin{array}{l}\text { Penetratio } \\
\mathrm{n} \text { (cm bsf) }\end{array}$ & $\begin{array}{l}\text { Studie } \\
\text { d } \\
\text { interv } \\
\text { al (cm) }\end{array}$ & $\begin{array}{c}\text { Studie } \\
\text { d } \\
\text { sample } \\
\text { s }\end{array}$ \\
\hline \multirow[t]{5}{*}{ A } & $\begin{array}{c}\text { Active } \\
\text { channel - } \\
\text { backgroun } \\
\text { d }\end{array}$ & $\begin{array}{l}\text { Multitub } \\
\mathrm{e}\end{array}$ & $\begin{array}{l}\text { CoL-A- } \\
\text { MTB03 }\end{array}$ & $\begin{array}{c}06^{\circ} 28^{\prime} 12.57 \\
0\end{array}$ & $\begin{array}{c}06^{\circ} 02^{\prime} 12.98 \\
8\end{array}$ & 4764 & 22 & $0-22$ & 11 \\
\hline & $\begin{array}{c}\text { Active } \\
\text { levee - } \\
\text { backgroun } \\
\text { d }\end{array}$ & $\begin{array}{l}\text { Multitub } \\
\mathrm{e}\end{array}$ & $\begin{array}{l}\text { CoL-A- } \\
\text { MTB02 }\end{array}$ & $\begin{array}{c}06^{\circ} 27^{\prime} 35.91 \\
7\end{array}$ & $06^{\circ} 02^{\prime} 4.741$ & 4759 & 22 & $0-22$ & 11 \\
\hline & $\begin{array}{c}\text { Active } \\
\text { levee - } \\
\text { backgroun } \\
\text { d }\end{array}$ & $\begin{array}{l}\text { Multitub } \\
\mathrm{e}\end{array}$ & $\begin{array}{l}\text { WACS- } \\
\text { A- } \\
\text { MTB03 }\end{array}$ & $\begin{array}{c}06^{\circ} 27^{\prime} 15.60 \\
0\end{array}$ & $\begin{array}{c}06^{\circ} 01^{\prime} 56.16 \\
0\end{array}$ & 4884 & 19 & $0-19$ & 10 \\
\hline & $\begin{array}{c}\text { Active } \\
\text { levee - } \\
\text { backgroun } \\
\text { d }\end{array}$ & $\begin{array}{l}\text { Gravity } \\
\text { core }\end{array}$ & $\begin{array}{l}\text { CoL-A- } \\
\text { CSO1 }\end{array}$ & $\begin{array}{c}06^{\circ} 27^{\prime} 45.35 \\
2\end{array}$ & $06^{\circ} 1^{\prime} 55.040$ & 4755 & 1145 & $\begin{array}{c}0- \\
1032.5\end{array}$ & 37 \\
\hline & $\begin{array}{l}\text { Vesicomyi } \\
\text { d habitat }\end{array}$ & $\begin{array}{l}\text { ROV } \\
\text { tube- } \\
\text { core }\end{array}$ & $\begin{array}{l}\text { WACS- } \\
\text { A- } \\
\text { PL435- } \\
\text { CT08 }\end{array}$ & $\begin{array}{c}06^{\circ} 26^{\prime} 54.25 \\
2\end{array}$ & $\begin{array}{c}06^{\circ} 01^{\prime} 55.68 \\
6\end{array}$ & 4750 & 16 & $0-16$ & 9 \\
\hline \multirow[t]{2}{*}{$F$} & $\begin{array}{c}\text { Active } \\
\text { levee - } \\
\text { backgroun } \\
d\end{array}$ & $\begin{array}{l}\text { Multitub } \\
\text { e }\end{array}$ & $\begin{array}{l}\text { CoL-F- } \\
\text { MTB05 }\end{array}$ & $\begin{array}{c}06^{\circ} 34^{\prime} 50.07 \\
9\end{array}$ & $\begin{array}{c}05^{\circ} 41^{\prime} 27.99 \\
4\end{array}$ & 4864 & 22 & $0-22$ & 11 \\
\hline & $\begin{array}{c}\text { Active } \\
\text { levee - } \\
\text { backgroun } \\
\text { d }\end{array}$ & $\begin{array}{l}\text { Gravity } \\
\text { core }\end{array}$ & $\begin{array}{l}\text { CoL-F- } \\
\text { CSO3 }\end{array}$ & $\begin{array}{c}06^{\circ} 34^{\prime} 55.60 \\
8\end{array}$ & $\begin{array}{c}05^{\circ} 41^{\prime} 37.29 \\
3\end{array}$ & 4866 & 1090 & $\begin{array}{c}0- \\
1018.5\end{array}$ & 31 \\
\hline \multirow[t]{3}{*}{ C } & $\begin{array}{c}\text { Active } \\
\text { channel - } \\
\text { backgroun } \\
\text { d }\end{array}$ & $\begin{array}{l}\text { Multitub } \\
\text { e }\end{array}$ & $\begin{array}{l}\text { CoL-C- } \\
\text { MTB01 } \\
1\end{array}$ & $\begin{array}{c}06^{\circ} 41^{\prime} 56.83 \\
4\end{array}$ & $\begin{array}{c}05^{\circ} 29^{\prime} 19.80 \\
4\end{array}$ & 4961 & 22 & $0-22$ & 11 \\
\hline & $\begin{array}{c}\text { Active } \\
\text { channel - } \\
\text { backgroun } \\
\text { d }\end{array}$ & $\begin{array}{l}\text { Multitub } \\
\text { e }\end{array}$ & $\begin{array}{l}\text { WACS- } \\
\text { C- } \\
\text { MTB04 }\end{array}$ & $\begin{array}{c}06^{\circ} 41^{\prime} 15.60 \\
0\end{array}$ & $\begin{array}{c}05^{\circ} 28^{\prime} 59.52 \\
0\end{array}$ & 4950 & 40 & $0-40$ & 17 \\
\hline & $\begin{array}{c}\text { Active } \\
\text { channel - }\end{array}$ & $\begin{array}{l}\text { Gravity } \\
\text { core }\end{array}$ & $\begin{array}{l}\text { CoL-C- } \\
\text { CSO4 }\end{array}$ & $\begin{array}{c}06^{\circ} 39^{\prime} 37.23 \\
0\end{array}$ & $\begin{array}{c}05^{\circ} 28^{\prime} 10.10 \\
2\end{array}$ & 4949 & 968 & $\begin{array}{l}50- \\
932\end{array}$ & 10 \\
\hline
\end{tabular}




\begin{tabular}{|c|c|c|c|c|c|c|c|c|}
\hline $\begin{array}{c}\text { Active } \\
\text { channel - } \\
\text { backgroun } \\
\text { d }\end{array}$ & $\begin{array}{l}\text { Gravity } \\
\text { core }\end{array}$ & $\begin{array}{l}\text { CoL-C- } \\
\text { CSO6 }\end{array}$ & $\begin{array}{c}06^{\circ} 41^{\prime} 57.09 \\
0\end{array}$ & $\begin{array}{c}05^{\circ} 29^{\prime} 19.78 \\
3\end{array}$ & 4954 & 910 & $\begin{array}{c}0- \\
850.5\end{array}$ & 39 \\
\hline $\begin{array}{c}\text { Active } \\
\text { levee - } \\
\text { backgroun } \\
\text { d }\end{array}$ & $\begin{array}{l}\text { Multitub } \\
\mathrm{e}\end{array}$ & $\begin{array}{l}\text { CoL-C- } \\
\text { MTB06 }\end{array}$ & $\begin{array}{c}06^{\circ} 40^{\prime} 15.95 \\
2\end{array}$ & $\begin{array}{c}05^{\circ} 28^{\prime} 24.05 \\
9\end{array}$ & 4951 & 22 & $0-22$ & 11 \\
\hline $\begin{array}{l}\text { Microbial } \\
\text { mats }\end{array}$ & $\begin{array}{l}\text { ROV } \\
\text { tube- } \\
\text { core }\end{array}$ & $\begin{array}{l}\text { WACS- } \\
\text { C- } \\
\text { PL436- } \\
\text { CT11 }\end{array}$ & $\begin{array}{c}06^{\circ} 42^{\prime} 11.80 \\
2\end{array}$ & $\begin{array}{c}05^{\circ} 29^{\prime} 18.96 \\
6\end{array}$ & 4946 & 18.5 & $0-18.5$ & 9 \\
\hline $\begin{array}{c}\text { Fringe } \\
\text { Vesicomyi } \\
\text { d habitat }\end{array}$ & $\begin{array}{l}\text { ROV } \\
\text { tube- } \\
\text { core }\end{array}$ & $\begin{array}{l}\text { WACS- } \\
\text { C- } \\
\text { PL437- } \\
\text { CT02 }\end{array}$ & $06^{\circ} 42^{\prime} 5.148$ & $\begin{array}{c}05^{\circ} 29^{\prime} 18.04 \\
2\end{array}$ & 4946 & 19.5 & $0-19.5$ & 11 \\
\hline $\begin{array}{c}\text { Fringe } \\
\text { Vesicomyi } \\
\text { d habitat }\end{array}$ & $\begin{array}{l}\text { ROV } \\
\text { tube- } \\
\text { core }\end{array}$ & $\begin{array}{l}\text { WACS- } \\
\text { C- } \\
\text { PL437- } \\
\text { CT08 }\end{array}$ & $06^{\circ} 42^{\prime} 4.722$ & $\begin{array}{c}05^{\circ} 29.17 .25 \\
8\end{array}$ & 4946 & 28 & $0-28$ & 13 \\
\hline $\begin{array}{l}\text { Black and } \\
\text { white } \\
\text { patch }\end{array}$ & $\begin{array}{l}\text { ROV } \\
\text { tube- } \\
\text { core }\end{array}$ & $\begin{array}{l}\text { CoL-C- } \\
\text { PL490- } \\
\text { CT03 }\end{array}$ & $\begin{array}{c}06^{\circ} 41^{\prime} 24.18 \\
0\end{array}$ & $\begin{array}{c}05^{\circ} 28^{\prime} 46.92 \\
0\end{array}$ & 4947 & 5 & $0-5$ & 5 \\
\hline $\begin{array}{l}\text { Black and } \\
\text { white } \\
\text { patch }\end{array}$ & $\begin{array}{l}\text { ROV } \\
\text { tube- } \\
\text { core }\end{array}$ & $\begin{array}{l}\text { CoL-C- } \\
\text { PL490- } \\
\text { CT04 }\end{array}$ & $\begin{array}{c}06^{\circ} 41^{\prime} 24.24 \\
0\end{array}$ & $\begin{array}{c}05^{\circ} 28^{\prime} 46.98 \\
0\end{array}$ & 4947 & 11 & $0-11$ & 8 \\
\hline $\begin{array}{l}\text { Black } \\
\text { patch }\end{array}$ & $\begin{array}{l}\text { ROV } \\
\text { tube- } \\
\text { core }\end{array}$ & $\begin{array}{l}\text { CoL-C- } \\
\text { PL490- } \\
\text { CT13 }\end{array}$ & $\begin{array}{c}06^{\circ} 40^{\prime} 57.12 \\
0\end{array}$ & $\begin{array}{c}05^{\circ} 28^{\prime} 54.96 \\
0\end{array}$ & 4844 & 17.5 & $0-17.5$ & 10 \\
\hline $\begin{array}{l}\text { Black } \\
\text { patch }\end{array}$ & $\begin{array}{l}\text { ROV } \\
\text { tube- } \\
\text { core }\end{array}$ & $\begin{array}{l}\text { CoL-C- } \\
\text { PL490- } \\
\text { CT15 }\end{array}$ & $\begin{array}{c}06^{\circ} 40^{\prime} 57.36 \\
0\end{array}$ & $\begin{array}{c}05^{\circ} 28^{\prime} 55.80 \\
0\end{array}$ & 4844 & 22 & $0-22$ & 11 \\
\hline $\begin{array}{l}\text { Vesicomyi } \\
\text { d habitat }\end{array}$ & $\begin{array}{l}\text { ROV } \\
\text { tube- } \\
\text { core }\end{array}$ & $\begin{array}{l}\text { CoL-C- } \\
\text { PL491- } \\
\text { CT01 }\end{array}$ & $\begin{array}{c}06^{\circ} \\
42^{\prime} 5.040\end{array}$ & $\begin{array}{c}05^{\circ} 29^{\prime} 17.58 \\
0\end{array}$ & 4946 & 13 & $0-13$ & 8 \\
\hline $\begin{array}{l}\text { Vesicomyi } \\
\text { d habitat }\end{array}$ & $\begin{array}{l}\text { ROV } \\
\text { tube- } \\
\text { core }\end{array}$ & $\begin{array}{l}\text { CoL-C- } \\
\text { PL491- } \\
\text { CT05 }\end{array}$ & $\begin{array}{c}06^{\circ} \\
42^{\prime} 5.100\end{array}$ & $\begin{array}{c}05^{\circ} \\
29^{\prime} 17.640\end{array}$ & 4946 & 13 & $0-13$ & 8 \\
\hline $\begin{array}{l}\text { Adjacent } \\
\text { Vesicomyi } \\
\text { d habitat }\end{array}$ & $\begin{array}{l}\text { ROV } \\
\text { tube- } \\
\text { core }\end{array}$ & $\begin{array}{l}\text { CoL-C- } \\
\text { PL491- } \\
\text { CT14 }\end{array}$ & $\begin{array}{c}06^{\circ} \\
42^{\prime} 5.580\end{array}$ & $\begin{array}{c}05^{\circ} \\
29^{\prime} 18.300\end{array}$ & 4846 & 22 & $0-22$ & 11 \\
\hline $\begin{array}{l}\text { Hemipelag } \\
\text { ic behind } \\
\text { lobe }\end{array}$ & $\begin{array}{l}\text { ROV } \\
\text { tube- } \\
\text { core }\end{array}$ & $\begin{array}{l}\text { WACS- } \\
\text { D- } \\
\text { PL438- } \\
\text { CT02 }\end{array}$ & $\begin{array}{c}06^{\circ} 47^{\prime} 33.16 \\
2\end{array}$ & $\begin{array}{c}05^{\circ} 12^{\prime} 47.67 \\
6\end{array}$ & 5028 & 18 & $0-18$ & 10 \\
\hline $\begin{array}{l}\text { Hemipelag } \\
\text { ic behind } \\
\text { lobe }\end{array}$ & $\begin{array}{l}\text { ROV } \\
\text { tube- } \\
\text { core }\end{array}$ & $\begin{array}{l}\text { WACS- } \\
\text { D- } \\
\text { PL438- } \\
\text { CT05 }\end{array}$ & $\begin{array}{c}06^{\circ} 47^{\prime} 33.16 \\
5\end{array}$ & $\begin{array}{c}05^{\circ} 12^{\prime} 47.67 \\
7\end{array}$ & 5028 & 10 & $0-10$ & 12 \\
\hline Distal zone & Gravity & WACS- & $06^{\circ} 44^{\prime} 22.00$ & $05^{\circ} 19^{\prime} 35.80$ & 4996 & 1980 & $0-$ & 105 \\
\hline
\end{tabular}




\begin{tabular}{|c|c|c|c|c|c|c|c|c|c|}
\hline & $\begin{array}{l}\text { of terminal } \\
\text { lobe }\end{array}$ & core & CS06 & 8 & 2 & & & 1980 & \\
\hline \multirow[t]{2}{*}{ B } & $\begin{array}{c}\text { Partly } \\
\text { active lobe }\end{array}$ & $\begin{array}{l}\text { Multitub } \\
\text { e }\end{array}$ & $\begin{array}{l}\text { CoL-B- } \\
\text { MTB12 }\end{array}$ & $\begin{array}{c}06^{\circ} 25^{\prime} 36.96 \\
4\end{array}$ & $\begin{array}{c}05^{\circ} 49^{\prime} 35.25 \\
3\end{array}$ & 4823 & 25 & $0-25$ & 11 \\
\hline & $\begin{array}{l}\text { Partly } \\
\text { active lobe }\end{array}$ & $\begin{array}{l}\text { Gravity } \\
\text { core }\end{array}$ & $\begin{array}{l}\text { CoL-B- } \\
\text { CSO7 }\end{array}$ & $\begin{array}{c}06^{\circ} 25^{\prime} 36.72 \\
0\end{array}$ & $\begin{array}{c}05^{\circ} 49^{\prime} 34.56 \\
0\end{array}$ & 4822 & 935 & $\begin{array}{c}0- \\
885.5\end{array}$ & 22 \\
\hline E & $\begin{array}{c}\text { Former } \\
\text { lobe (> } 10 \\
\text { ka) }\end{array}$ & $\begin{array}{l}\text { Multitub } \\
\mathrm{e}\end{array}$ & $\begin{array}{l}\text { CoL-E- } \\
\text { MTB14 }\end{array}$ & $\begin{array}{c}06^{\circ} 05^{\prime} 53.63 \\
5\end{array}$ & $\begin{array}{c}05^{\circ} 54^{\prime} 29.06 \\
9\end{array}$ & 4750 & 22 & $0-22$ & 11 \\
\hline
\end{tabular}

Table 2 - Rock-Eval signature of the terrestrial and marine source end-members for the Congo deepsea fan. The six samples, collected near Kinshasa (detailed location in Talbot et al., 2014), provide signature of the continental source. The data for the sediment trap at site $A$ are an average of the material collected during a 10-months mooring ( $45 \mathrm{~m}$ above sea level) and represent the marine signature.

\begin{tabular}{|c|c|c|c|c|c|c|c|c|c|c|c|c|}
\hline Site & Depth & $\begin{array}{c}\text { S1 } \\
\text { (mg } \\
\mathrm{HC} / \mathrm{g})\end{array}$ & $\begin{array}{c}\text { S2 } \\
\text { (mg } \\
\mathrm{HC} / \mathrm{g})\end{array}$ & $\left({ }^{\circ} \mathrm{C}\right)$ & $\begin{array}{c}\mathrm{S3} \\
(\mathrm{mg} \\
\left.\mathrm{CO}_{2} / \mathrm{g}\right)\end{array}$ & $\begin{array}{r}\text { TOC } \\
(\%)\end{array}$ & $\begin{array}{c}\mathrm{HI} \\
\text { (mg } \\
\mathrm{HC} / \mathrm{g} \\
\mathrm{TOC})\end{array}$ & $\begin{array}{c}\text { OI } \\
\text { (mg } \\
\mathrm{CO}_{2} / \mathrm{g} \\
\mathrm{TOC})\end{array}$ & $\begin{array}{c}\text { MinC } \\
\text { (\%) } \\
(\%)\end{array}$ & $\begin{array}{c}\mathrm{CaCO}_{3} \\
\text { eq. } \\
\text { (\%) }\end{array}$ & $\begin{array}{c}\delta \delta \\
{ }^{13} C_{\text {org }} \\
(\% \circ)\end{array}$ & $C / N$ \\
\hline Bedload & surface & 0.02 & 2.70 & 419 & 3.91 & 1.51 & 178 & 258 & 0.17 & 1.4 & nd & nd \\
\hline Bedload & subsurface & 0.01 & 1.93 & 418 & 2.86 & 1.17 & 165 & 244 & 0.18 & 1.5 & nd & nd \\
\hline Floodplain & surface & 0.01 & 2.10 & 414 & 3.16 & & & 260 & 0.13 & 1.1 & nd & nd \\
\hline Floodplain & subsurface & 0.01 & 2.88 & 414 & 4.58 & 1.73 & 166 & 265 & 0.19 & 1.6 & nd & nd \\
\hline Riverndbank & surface & 0.02 & 4.60 & 419 & 7.64 & 2.56 & 180 & 299 & 0.38 & 3.2 & nd & nd \\
\hline Riverndbank & subsurface & 0.02 & 4.30 & 418 & 8.00 & 2.45 & 176 & 327 & 0.39 & 3.2 & nd & nd \\
\hline Sed. trap A & $45 \mathrm{~m}$ asf* & 0.11 & 14.73 & 419 & 8.45 & 4.80 & 306 & 198 & 4.79 & 39.9 & $\begin{array}{c}- \\
23.7\end{array}$ & 8.3 \\
\hline
\end{tabular}

nd : note determined 
Table 3 - Sedimentation rates and Corg percentages in selected 'organic-rich' turbidite systems.

\begin{tabular}{|c|c|c|c|c|c|c|c|c|c|}
\hline \multirow[t]{2}{*}{ Area } & \multirow{2}{*}{$\begin{array}{c}\text { Wat } \\
\text { er } \\
- \\
\text { dep } \\
\text { th } \\
\text { (m) }\end{array}$} & \multicolumn{3}{|c|}{$\begin{array}{c}\text { Sedimentation } \\
\text { rate }(\mathrm{cm} / \mathrm{ky})\end{array}$} & \multirow[t]{2}{*}{ References } & \multicolumn{3}{|c|}{ Corg (\%) } & \multirow[t]{2}{*}{ References } \\
\hline & & $\begin{array}{c}\mathrm{Mi} \\
\mathrm{n}\end{array}$ & $\begin{array}{l}\text { Me } \\
\text { an }\end{array}$ & $\begin{array}{c}\text { Ma } \\
\mathbf{x}\end{array}$ & & $\begin{array}{c}\text { Mi } \\
\mathrm{n}\end{array}$ & $\begin{array}{l}\text { Me } \\
\text { an }\end{array}$ & $\begin{array}{l}M \\
\text { ax }\end{array}$ & \\
\hline Congo lobe complex & $\begin{array}{c}500 \\
0\end{array}$ & $\begin{array}{l}10 \\
00\end{array}$ & $\begin{array}{c}190 \\
0\end{array}$ & $\begin{array}{c}100 \\
00\end{array}$ & $\begin{array}{l}\text { Rabouille et al., } \\
\text { 2009; this } \\
\text { volume }\end{array}$ & $\begin{array}{l}2 . \\
9\end{array}$ & 3.5 & 5.5 & $\begin{array}{l}\text { Stetten et al., } \\
2015 \text {; this } \\
\text { study }\end{array}$ \\
\hline $\begin{array}{l}\text { Congo channel- } \\
\text { levee complex }\end{array}$ & $\begin{array}{c}400 \\
0\end{array}$ & 44 & - & 650 & $\begin{array}{l}\text { Migeon et al., } \\
2004\end{array}$ & $\begin{array}{l}1 . \\
4\end{array}$ & 3.0 & 5.6 & $\begin{array}{l}\text { Baudin et al., } \\
2010\end{array}$ \\
\hline $\begin{array}{l}\text { Ogooué turbiditic } \\
\text { system }\end{array}$ & 800 & $\begin{array}{c}70 \\
0\end{array}$ & $\begin{array}{c}100 \\
0\end{array}$ & $\begin{array}{c}170 \\
0\end{array}$ & $\begin{array}{l}\text { Biscara et al., } \\
2012\end{array}$ & $\begin{array}{l}1 . \\
0\end{array}$ & 4.0 & $\begin{array}{l}14 . \\
0\end{array}$ & $\begin{array}{l}\text { Biscara et al., } \\
2012\end{array}$ \\
\hline $\begin{array}{l}\text { Amazon fan (glacial } \\
\text { period) }\end{array}$ & $\begin{array}{c}300 \\
0\end{array}$ & $\begin{array}{c}97 \\
0\end{array}$ & - & $\begin{array}{c}172 \\
4\end{array}$ & $\begin{array}{l}\text { Schlünz et al., } \\
1999\end{array}$ & $\begin{array}{l}0 . \\
7\end{array}$ & 0.8 & 1.0 & $\begin{array}{l}\text { Schlünz et al., } \\
1999\end{array}$ \\
\hline Bengal fan (lobes) & $\begin{array}{c}400 \\
0\end{array}$ & - & 56 & - & $\begin{array}{l}\text { Curray et al., } \\
2003\end{array}$ & 0. & 0.4 & 0.8 & Galy et al., 2007 \\
\hline $\begin{array}{l}\text { Iberian margin- } \\
\text { Nazaré canyon }\end{array}$ & $\begin{array}{c}300 \\
0\end{array}$ & - & 480 & - & $\begin{array}{l}\text { van Weering et } \\
\text { al., } 2002\end{array}$ & - & 4.0 & - & $\begin{array}{l}\text { van Weering et } \\
\text { al., } 2002\end{array}$ \\
\hline
\end{tabular}

\section{Highlights}

- High organic carbon content (up to $5 \mathrm{wt} \%$ ) of terrestrial origin in the lobe complex

- Homogeneous distribution of organic matter in space and over time

- Same geochemical characteristics in lobe complex as in channel-levee systems of the Congo deep-sea fan

- Rock-Eval data match $\mathrm{C} / \mathrm{N}$ and $\delta^{13} \mathrm{C}_{\text {org }}$ data

- Lobe sediments are an important sink for terrestrial organic carbon 


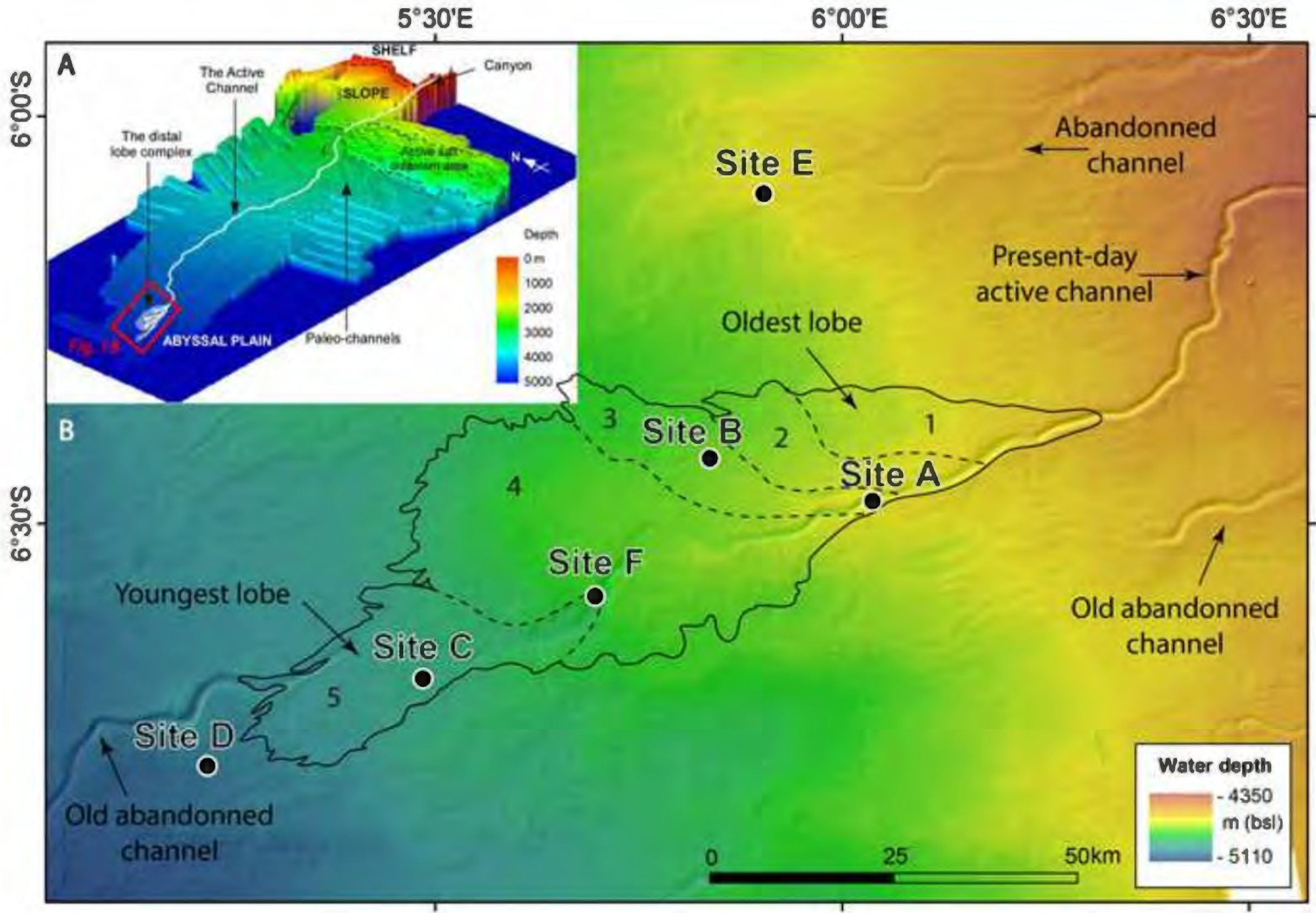



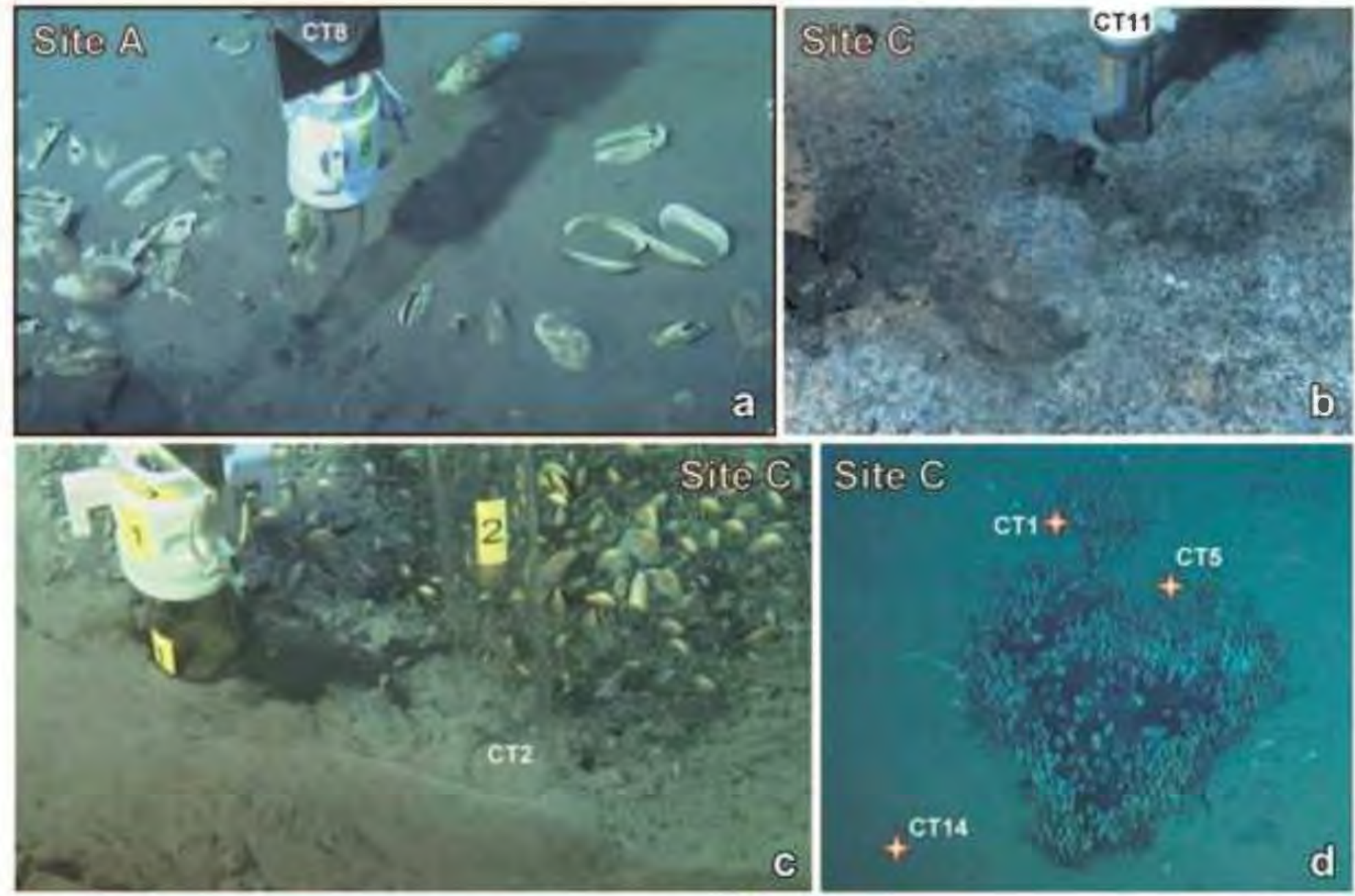

Site G

C

CT1

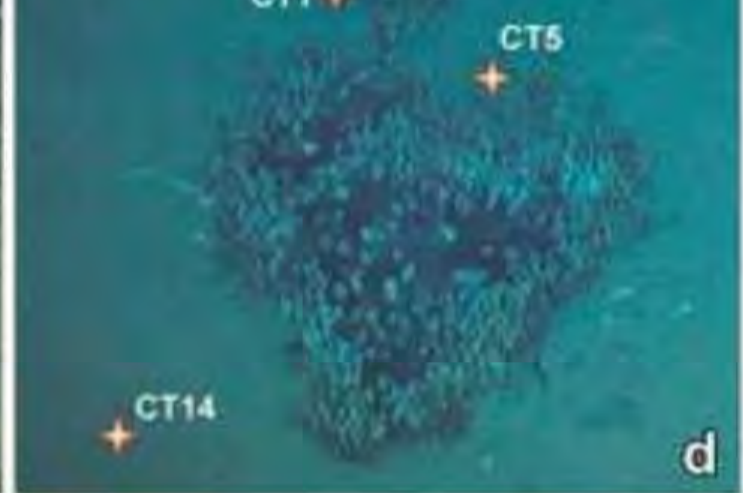

Site C

Site D

$$
\mathrm{CT}_{13}++\mathrm{CT} 15
$$

e

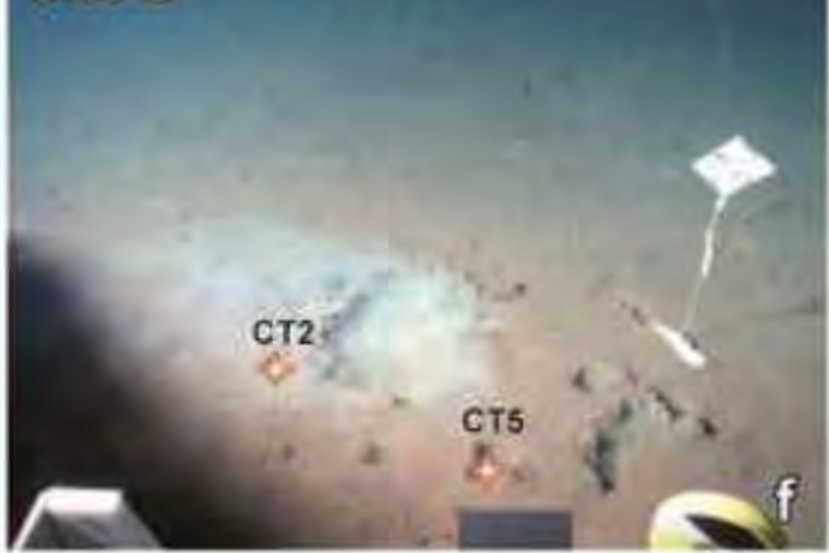




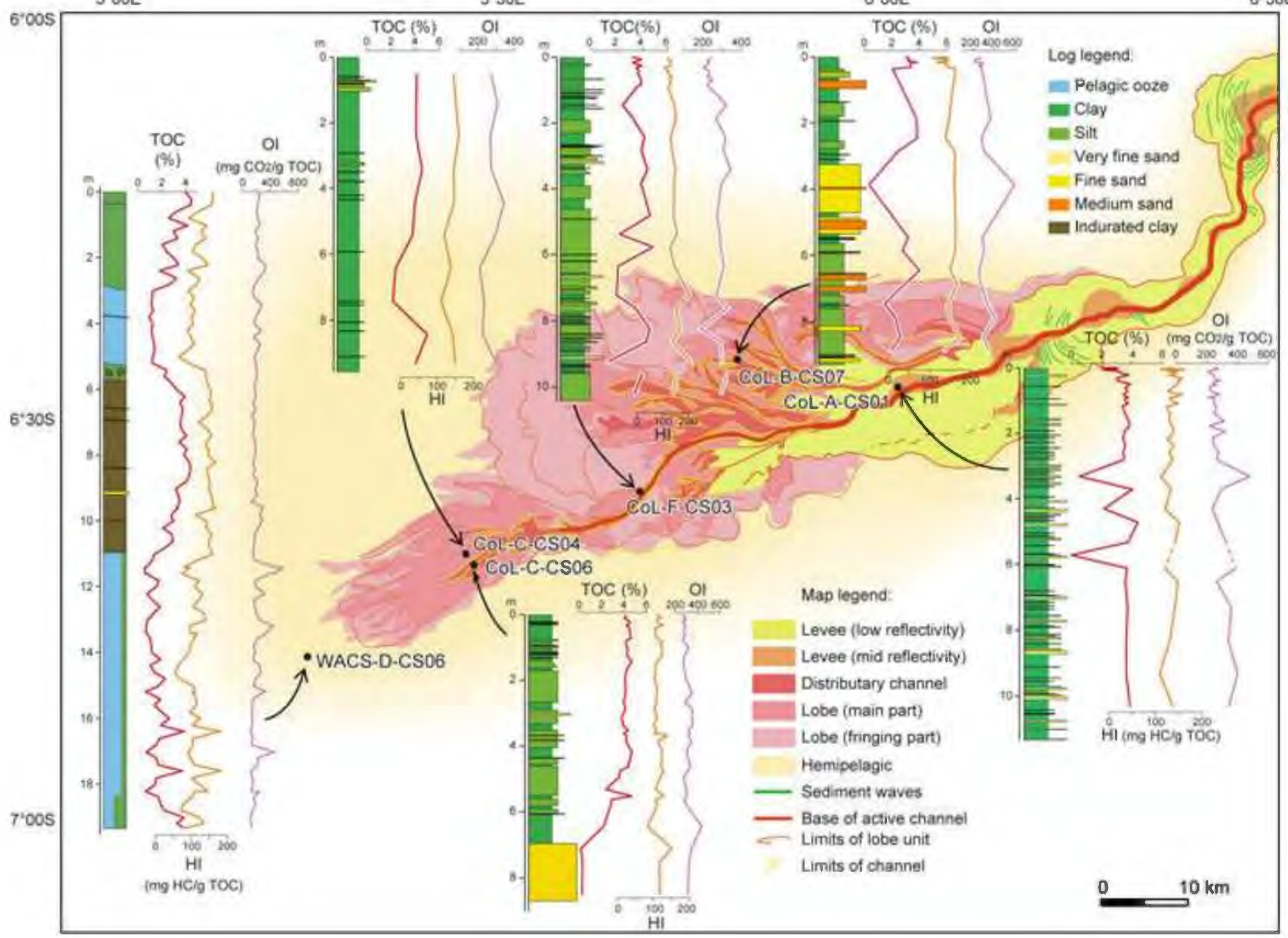




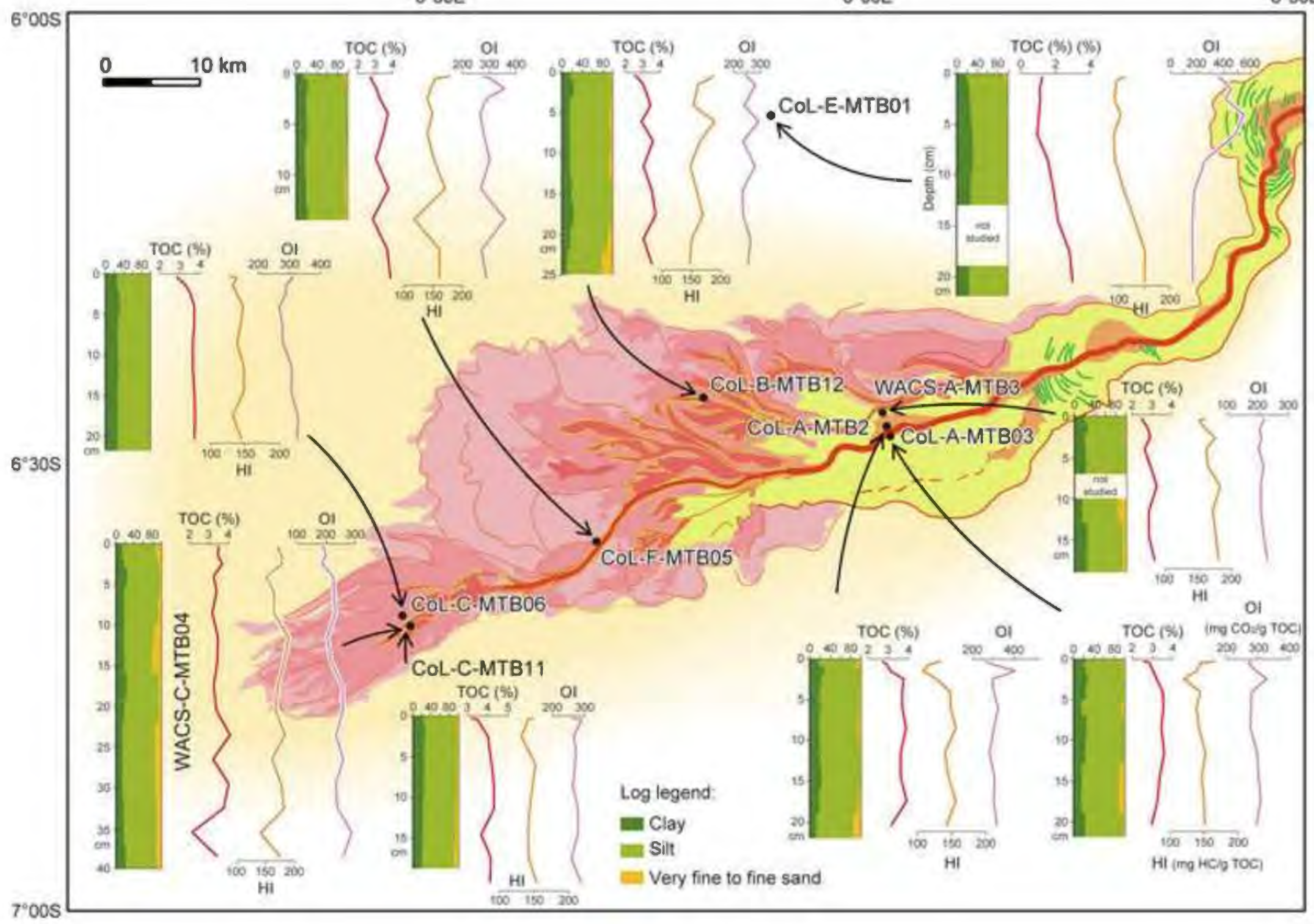



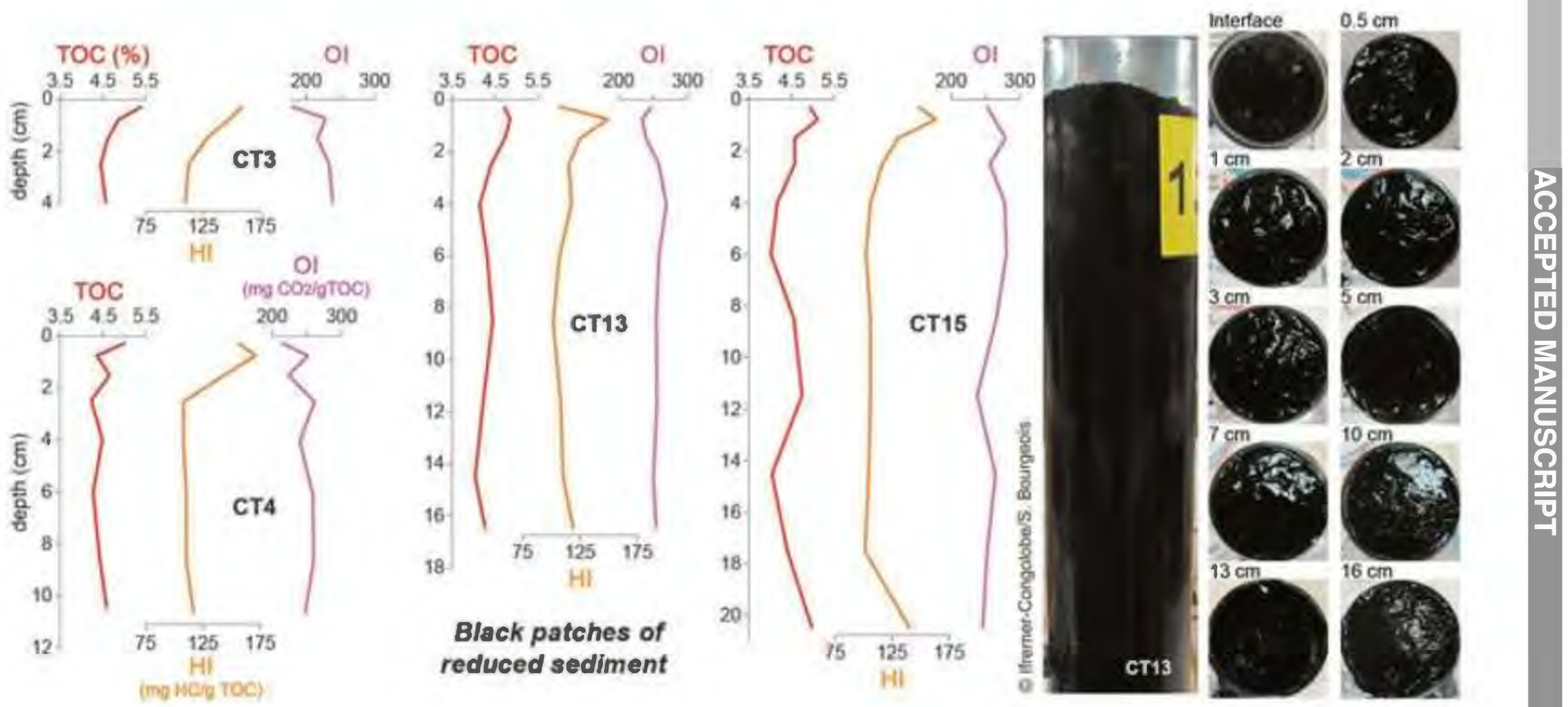


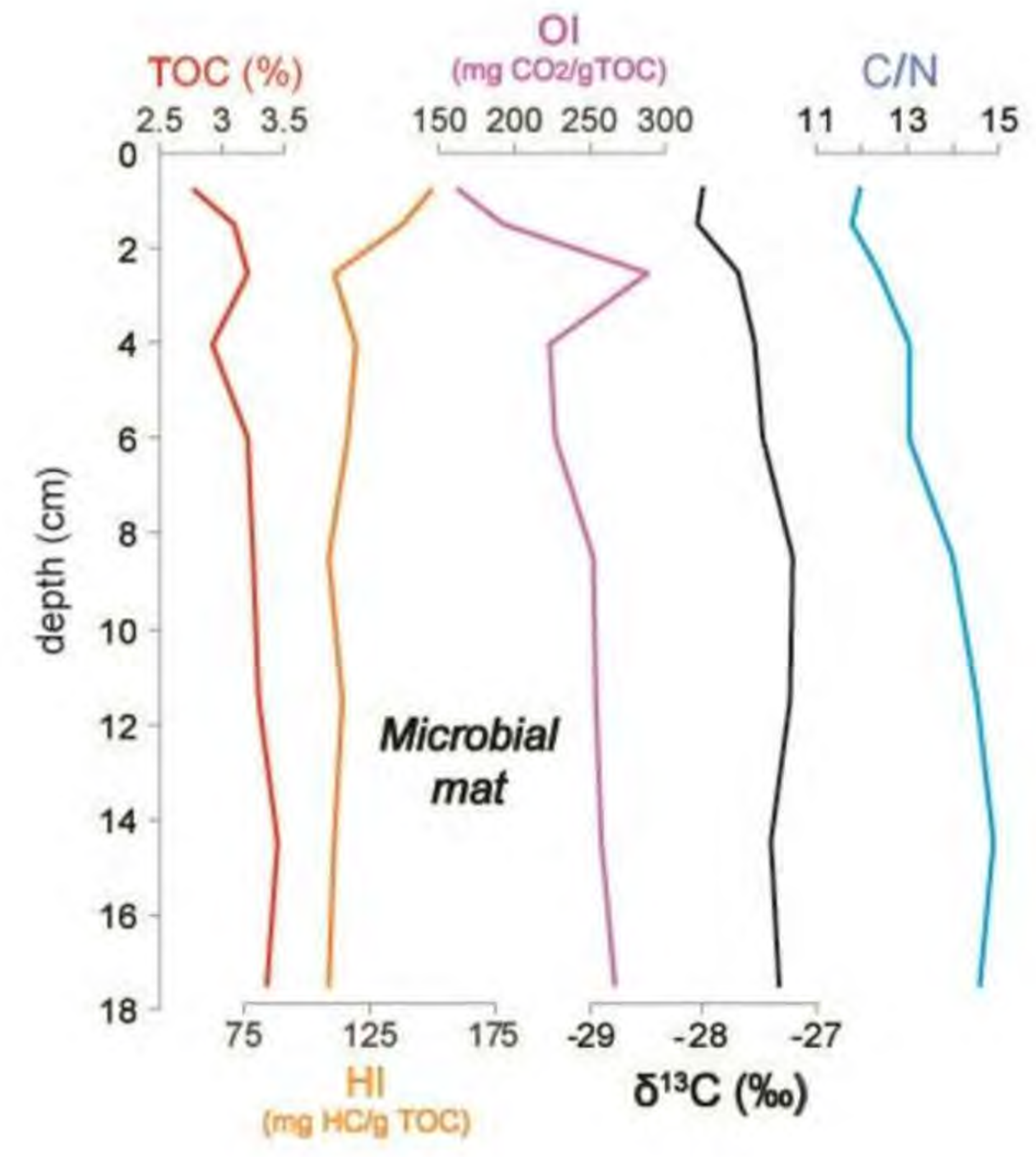

Figure 6

OI 


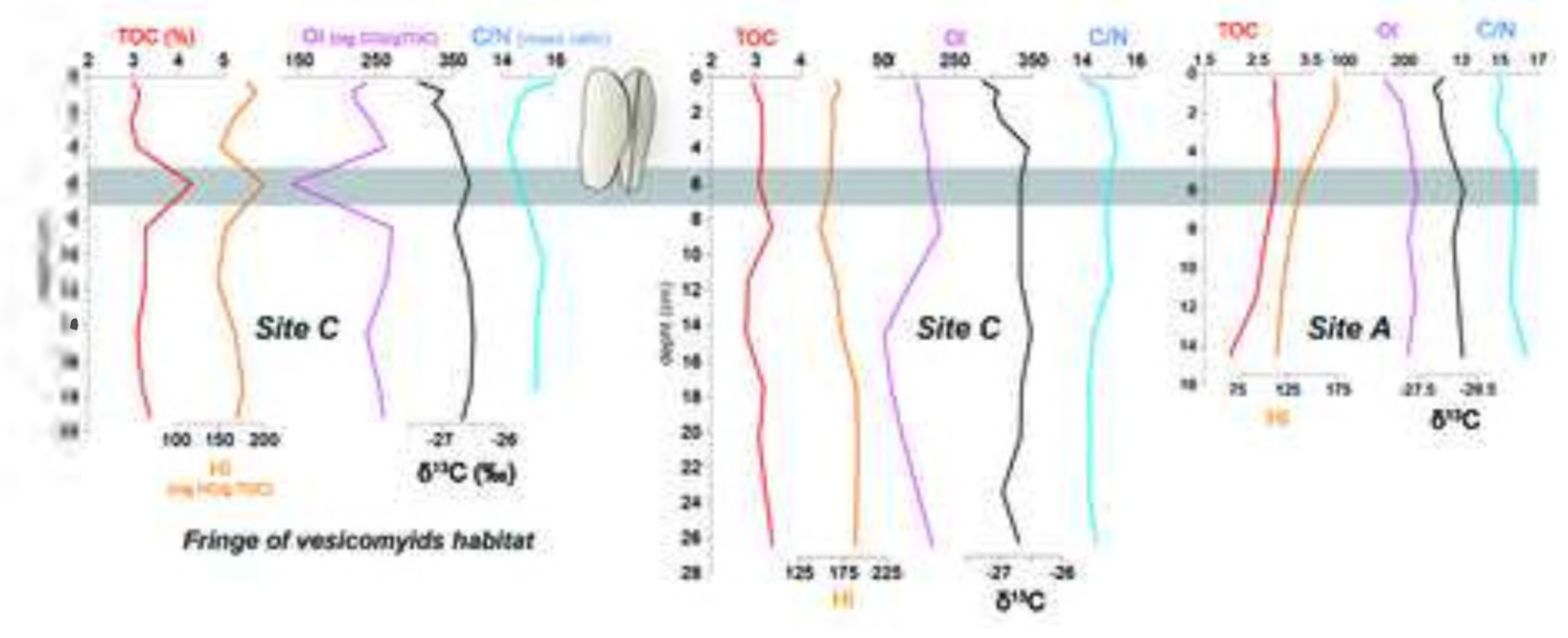

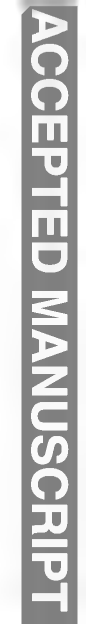

Figur

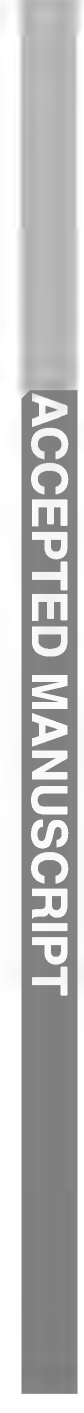



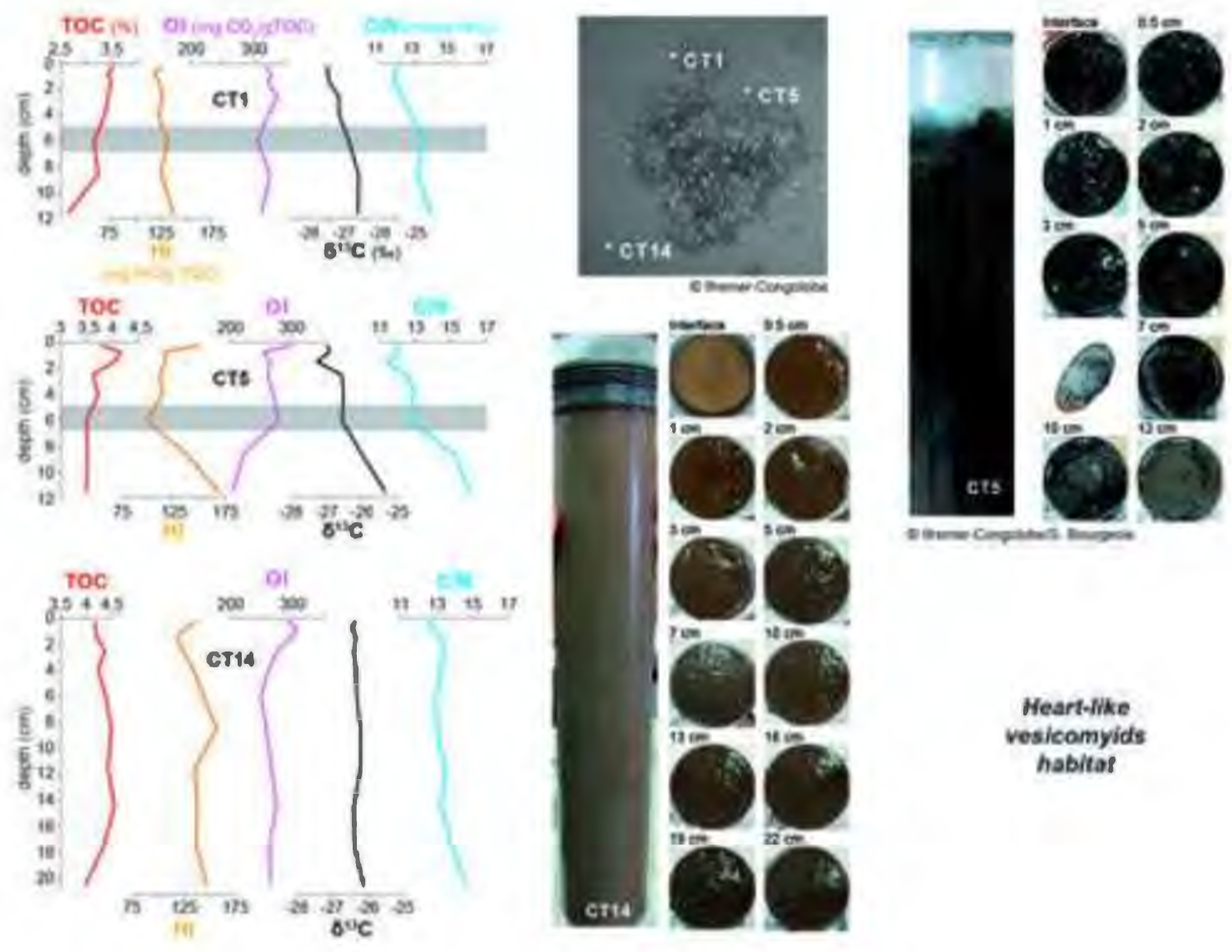

\author{
Heart-inke \\ vesicamyids \\ habitas
}




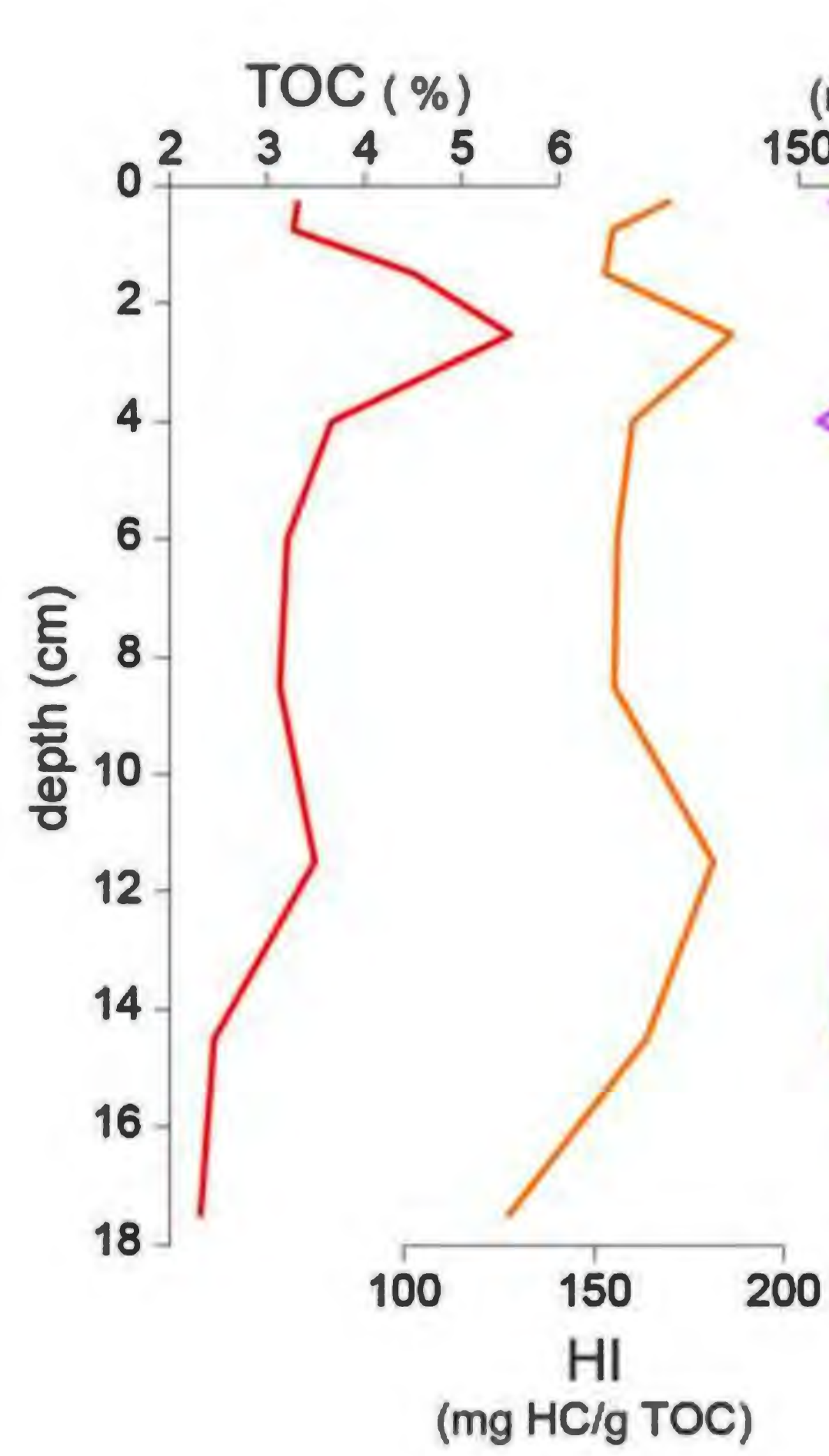

OI

(mg CO2/gTOC)

$\mathrm{C} / \mathrm{N}$ (mass ratio)

350

Sediments with

Bathysiphon
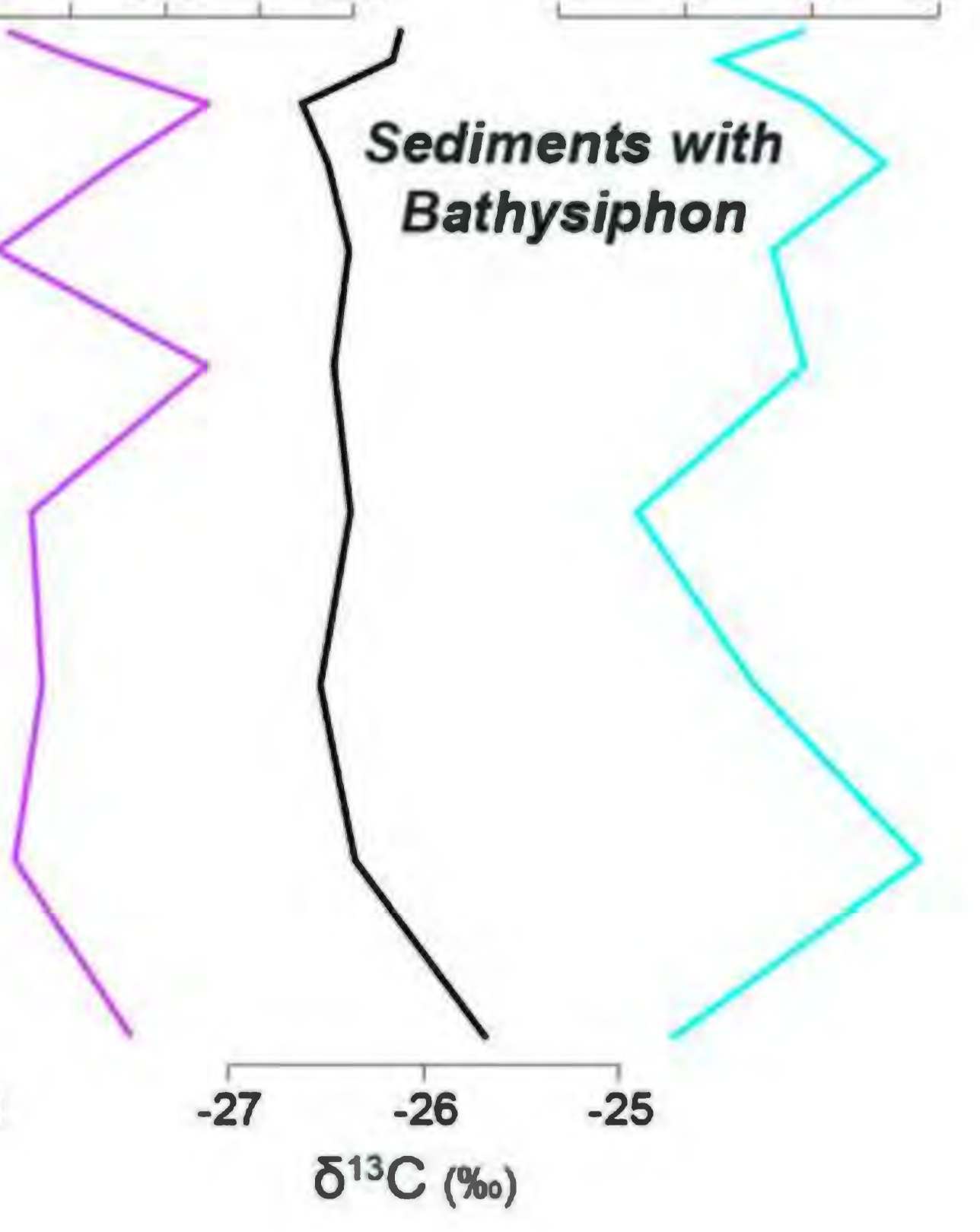$$
\text { - }
$$ 


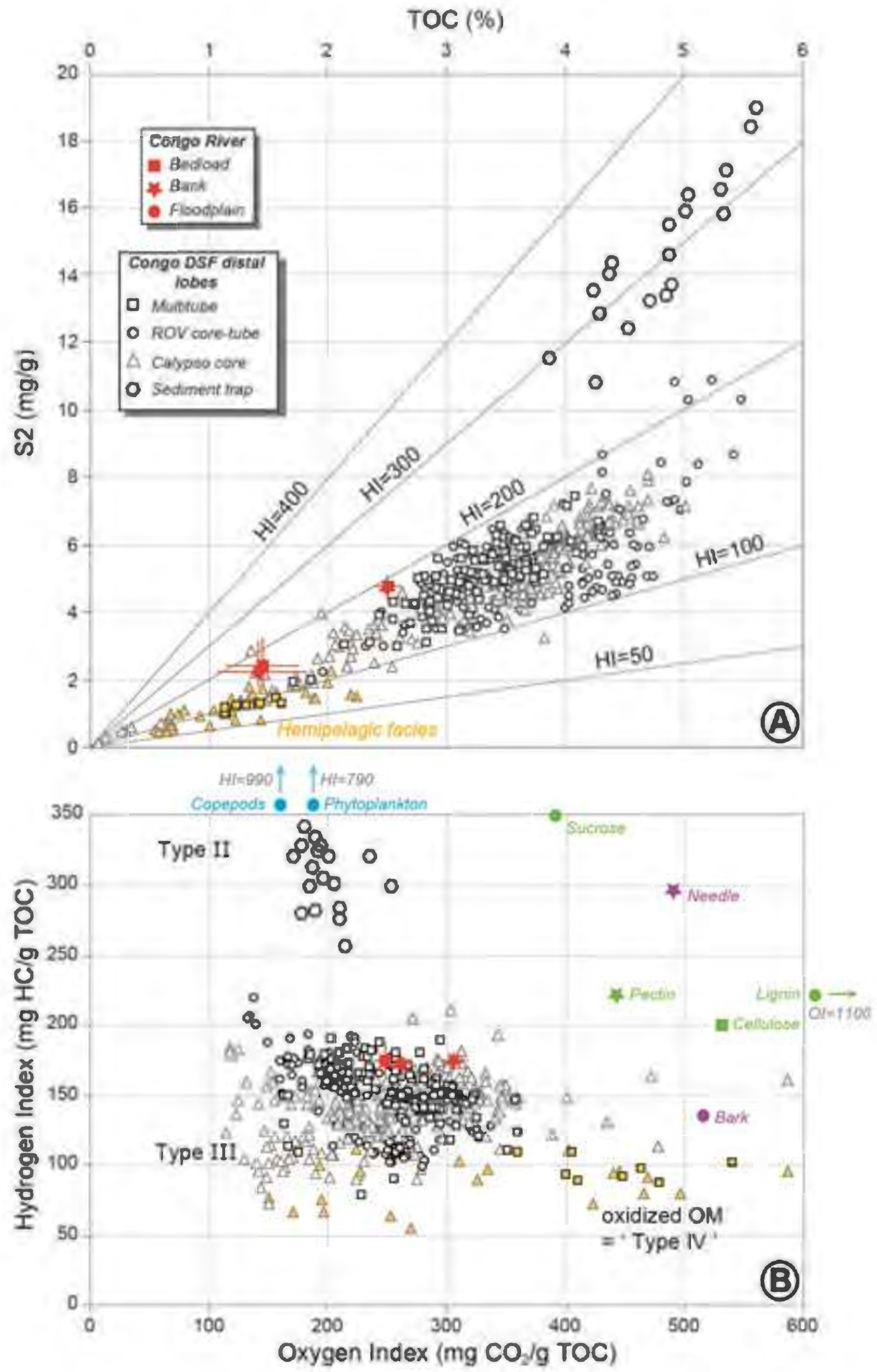




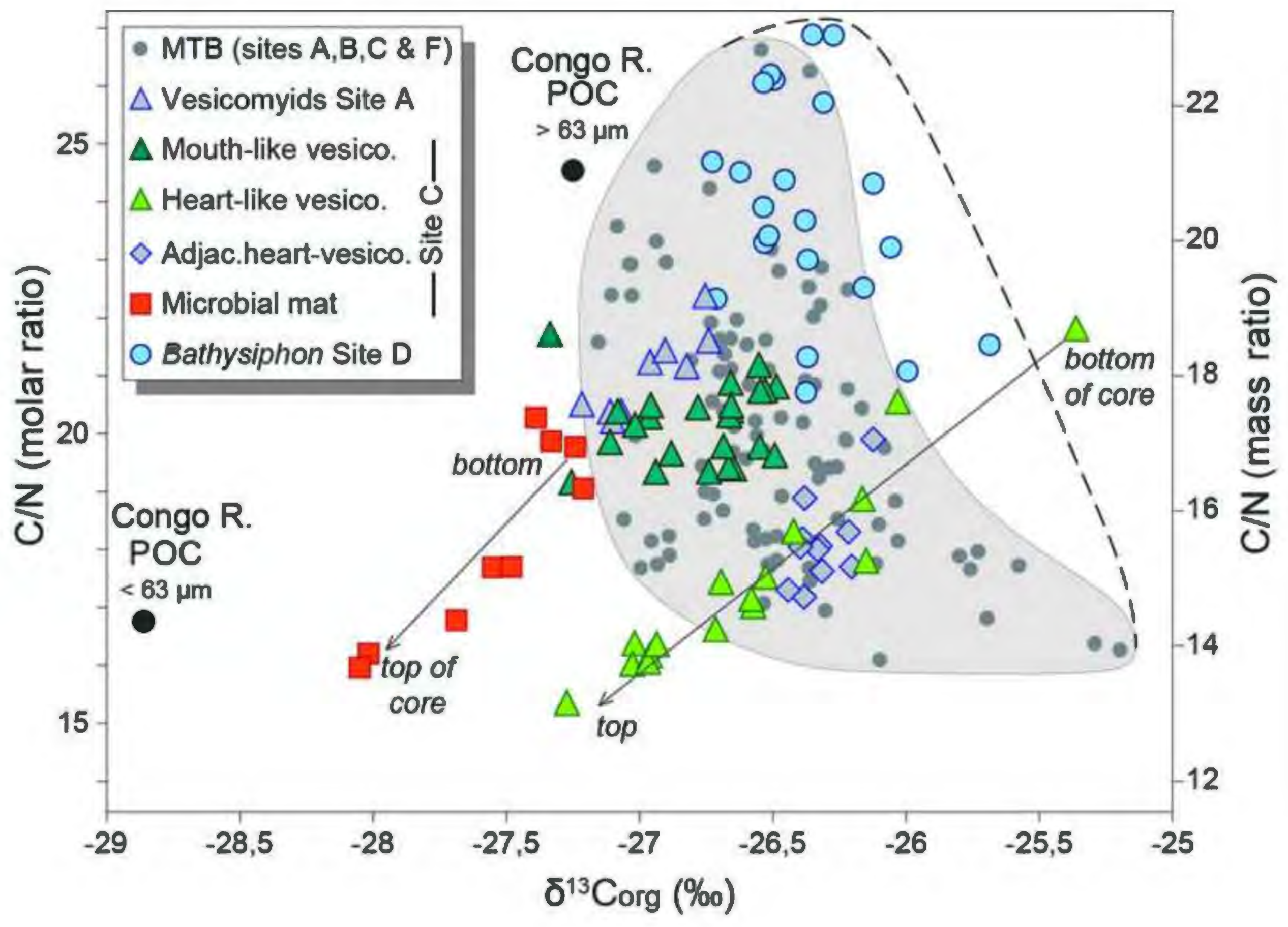




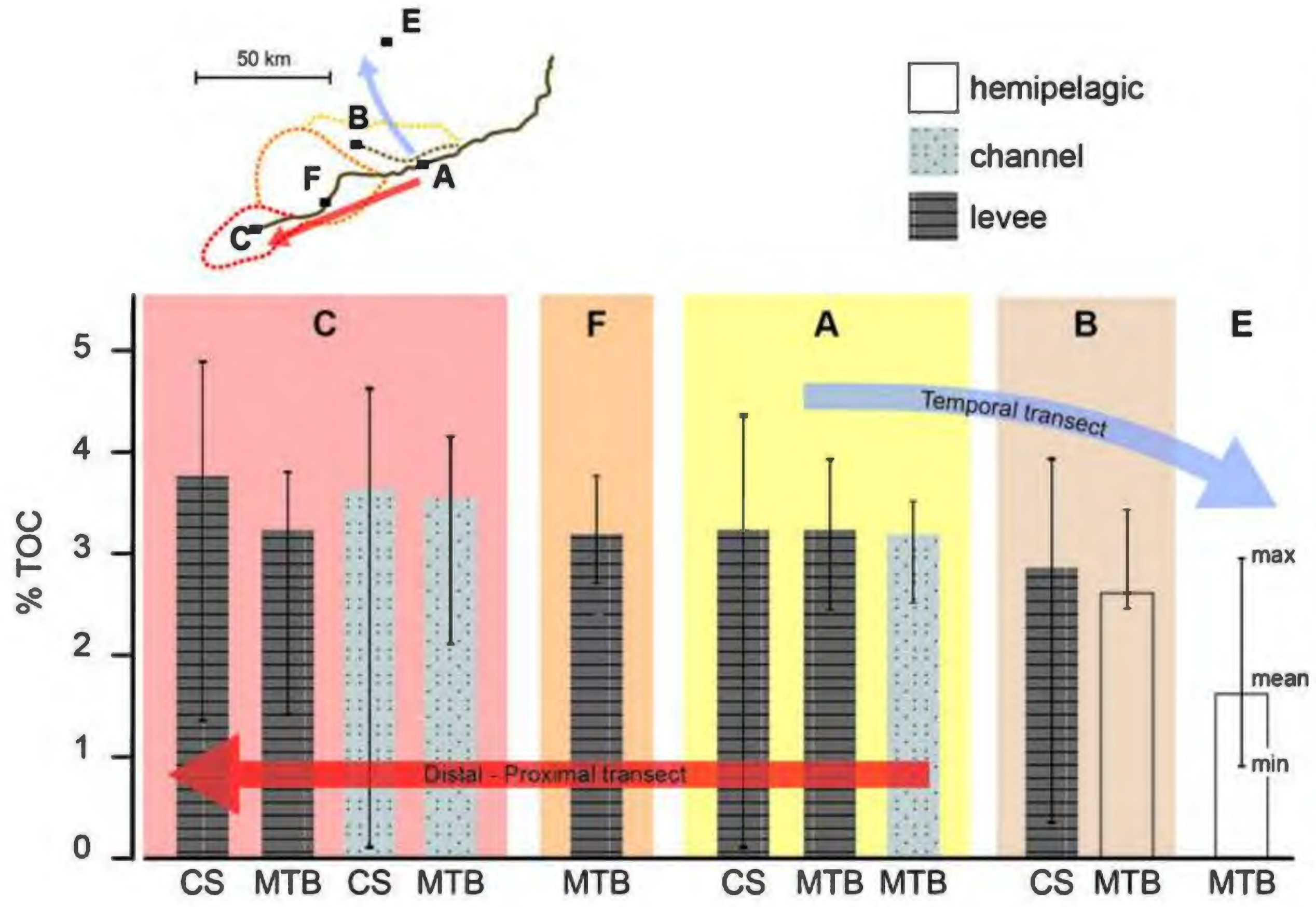




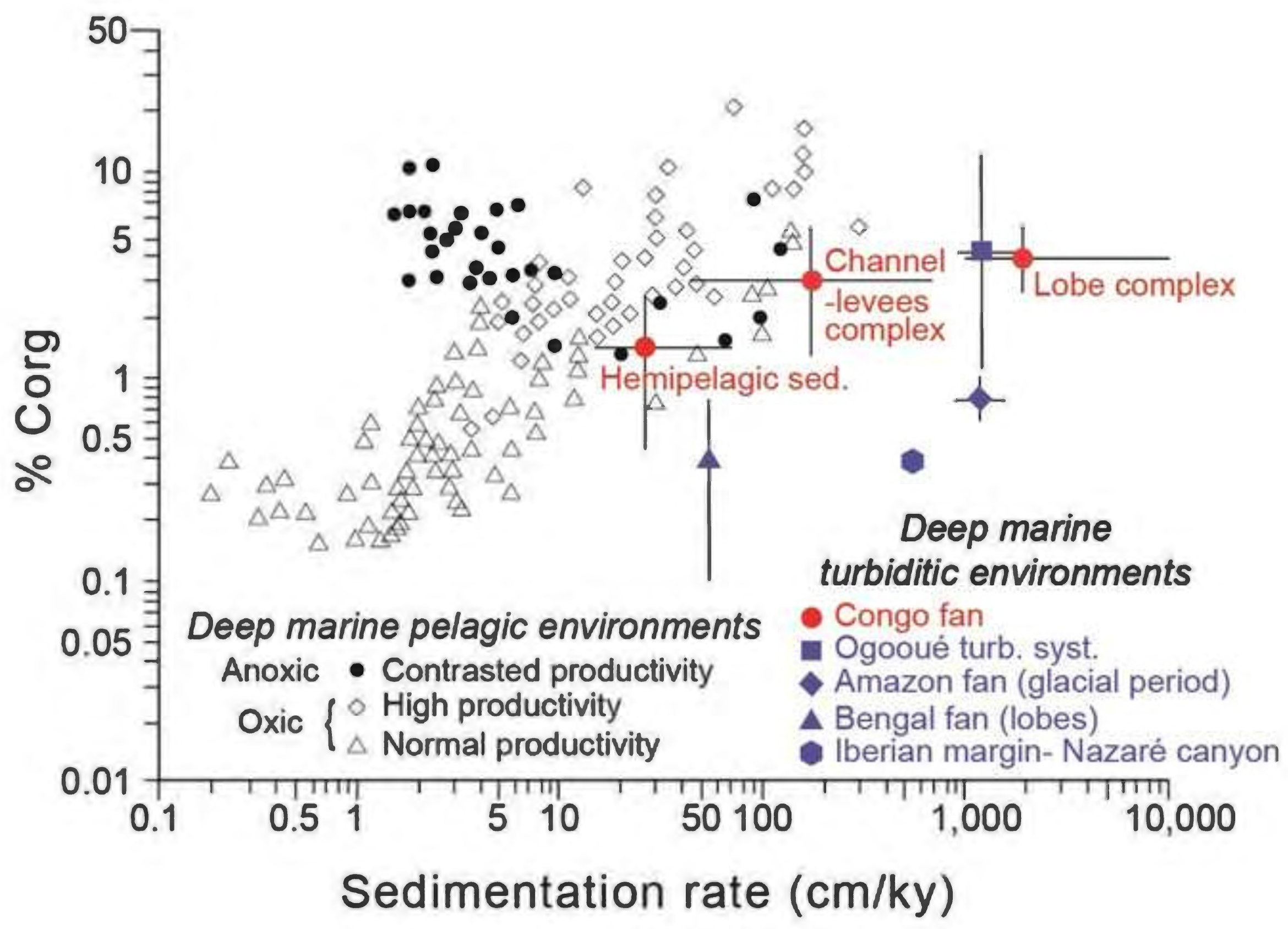

